Document downloaded from:

http://hdl.handle.net/10251/62227

This paper must be cited as:

Pellicer Armiñana, TM.; Pellicer Armiñana, E.; Eaton, D. (2009). A macroeconomic regression analysis of the European construction industry. Engineering, Construction and Architectural Management. 16(6):573-597. doi:10.1108/09699980911002584.

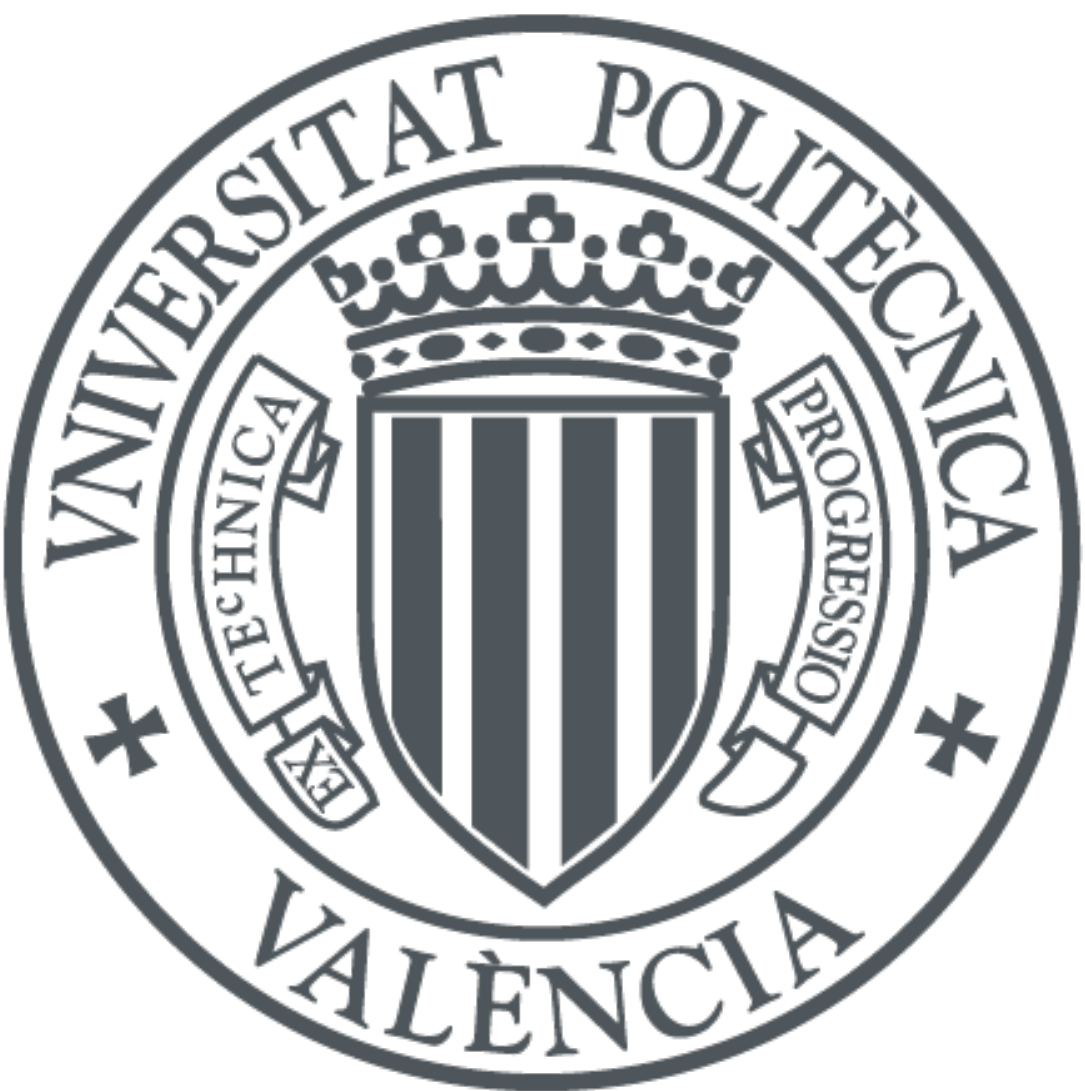

The final publication is available at

http://dx.doi.org/10.1108/09699980911002584

Copyright Emerald

Additional Information 


\title{
A MACROECONOMIC REGRESSION ANALYSIS OF THE EUROPEAN CONSTRUCTION INDUSTRY
}

\author{
Teresa M. Pellicer \\ Assistant Professor, M.Arch., Ph.D. \\ School of Civil Engineering \\ Universidad Politécnica de Valencia \\ Camino de Vera, s/n, 46022 Valencia, Spain \\ Phone:+34.963.877.562; Fax:+34.963.877.569; E-mail:tpa@cst.upv.es \\ Eugenio Pellicer ${ }^{1}$ \\ Associate Professor, M.Sc., Ph.D. \\ School of Civil Engineering \\ Universidad Politécnica de Valencia \\ Camino de Vera, s/n, 46022 Valencia, Spain \\ Phone:+34.963.879.562; Fax:+34.963.877.569; E-mail:pellicer@cst.upv.es
}

\author{
David Eaton \\ Professor, M.Sc., Ph.D.
}

School of the Built Environment

The Crescent, Salford, Greater Manchester, M5 4WT United Kingdom

Phone:+44.161.295.5222; Fax:+44.161.295.5011; E-mail:d.eaton@salford.ac.uk

WORD COUNT (from this point on): 5375 words +9 tables

${ }^{1}$ Corresponding author 


\section{PURPOSE:}

This paper analyses the international construction sector from a macroeconomic point of view through production functions. The aim is to contribute additional knowledge on the European construction sector, highlighting differences in the industry among European countries

\section{DESIGN/METHODOLOGYIAPPROACH:}

In order to analyse the sector panel data from 1996-2005 for nine European countries were used. Raw data was obtained from Eurostat (Bach Project). Variables for the production functions were chosen after a correlation analysis. Annual turnover was taken as the dependent variable, whereas total assets and personnel costs were the independent variables. The econometric regression models considered were linear (bivariate and multivariate) and logarithmic (CobbDouglas)

\section{FINDINGS:}

In spite of the limitations stated bellow, there are some factors that can explain the results obtained, such as the diverse preponderance of small and medium enterprises and the different roles played by informal economy, migration and subcontracting in each of the countries.

\section{RESEARCH LIMITATIONS/IMPLICATIONS:}

Data collected by Eurostat is provided by the enterprises voluntarily. This implies a bias in the representativeness of the data. Thus, the discrepancies and inconsistencies in the results obtained are a direct consequence of the data limitations. Furthermore, the regression models obtained should be tested using 
future data to predict the behaviour of the construction industry in each one of the countries.

\section{ORIGINALITYIVALUE:}

The use of production functions in the construction industry is a novel approach that should be further developed to gather more precise information on the behaviour of the sector.

KEYWORDS: Europe - Macroeconomics - Production Functions - Construction Sector - SMEs

CATEGORY OF PAPER: Research paper 


\section{A MACROECONOMIC REGRESSION ANALYSIS OF THE EUROPEAN CONSTRUCTION INDUSTRY}

\section{ABSTRACT}

The construction industry is vital for economies as a whole, even though it is not as fully analysed as are other sectors. The lack of scholarly attention is more pronounced when international construction is examined from a macroeconomic point of view. In order to fill partially this gap, a macro-economic regression analysis approach to the international construction sector of Europe is described in this paper. It analyses the European construction industry from two dimensions: time and country. Data from 1996-2005 for nine countries were used. The analysis was performed using production functions. Regression models were constructed that could be tested using future data to predict the behaviour of the construction industry in each of the countries. The discrepancies and inconsistencies in the results obtained were a direct consequence of the limitations of the data. Nevertheless, among the significant factors which explain the results are the diverse preponderance of small and medium enterprises and the different contributions of the informal economy, migration and subcontracting in each of the countries.

KEYWORDS: Europe - Macroeconomics - Production Functions - Construction Companies 


\section{INTRODUCTION}

Construction activity within the EU-27 in 2006 (FIEC, 2007) generated almost 1,200 Billion Euros (10.4\% of the EU's Gross Domestic Product) and it engaged more than 15 million people (more than $7 \%$ of all employment), being the largest industrial employer in the EU-27. Furthermore, the sector is formed by more than 2.7 million companies, mostly small and medium enterprises or SMEs (FIEC, 2007).

During recent years, five countries have contributed more than threequarters of the total production of the EU (Eurostat, 2007; Seopan, 2007): Germany, the United Kingdom, France, Italy and Spain. In the construction industry, there is a clear north/south distinction; some countries (France or Spain, for instance) maintain rigid and inflexible systems based on Roman Law and Napoleonic Codes, whereas other countries (the United Kingdom mainly) rely more on liberal market values and Common Law, and the others remain somewhere in the middle (Winch, 2000). Nevertheless, even though the industry is crucial for economies as a whole, it has not been subjected to analysis as have other sectors. The lack of research is even more problematic when the focus is international construction and when macroeconomic data are needed.

On a European level, the lack of academic scrutiny is also pronounced. Janssen (2000) examined the competitiveness of the industry in the EU from three aspects: investment, production and the labour process. Winch (2000) highlighted differences among country members inside the Union. Druker and Croucher (2000) analysed working practices in Europe, specially the use of overtime and the type of contracts, including subcontracting. Clarke and Wall (2000) characterised the division of labour in the United Kingdom, Germany and The Netherlands. Several years later, Lillie and Greer (2007) evaluated European 
policy making on labour in the United Kingdom, Germany and Finland, while Fellini et al. (2007) explored international migration flows affecting the European construction industry. Finally, innovation in the European construction industry has been addressed by several authors using different approaches (Pries and Janszen, 1995; Gann, 2000; Miozzo and Dewick, 2002; Eurostat, 2002).

On a larger scale, other researchers (Bon, 1988, Bon and Pietroforte, 1990, Bon, 2000, Pietroforte and Gregori, 2003) examined the macroeconomic indicators of the construction industries of several highly developed countries over a period of 20 years using input-output tables. They identified two important characteristics: the decreasing economic importance of the industry to a national economy and the transformation of its technologies. Bon and Crosthwaite (2001) extended this work to incorporate international activity of national industries, to identify market trends at the regional, national and metropolitan level.

Other authors (Ruddock, 2000 \& 2002; Ruddock and Lopes, 2006) indicated the limitations of this approach and suggested that time series statistics of one country, rather than cross-sectional data across countries, was a more effective approach to permit the identification of trends. In a further study, Lopes et al. (2002) applied these recommendations to developing countries in subSaharan Africa.

Huan and Pin (2000) listed a number of successful examples of implementation of regression techniques to the construction industry in order to model relationships among variables, quantifying how a dependent variable is linked to a set of explanatory variables; these models were also used as forecasting tools. Wong et al. (2007) and Dikmen et al. (2009) examined the complexities of the Hong Kong and Turkish construction industries respectively, utilising time series data and causal relationship analysis. This paper takes the procedures developed by these authors and utilises a multi-variable production 
function regression approach to analyse both cross-sectional and time series data for a selection of European construction industries to identify key variables and likely trends in macro-economic performance indicators.

\section{PURPOSE AND STRUCTURE OF THE PAPER}

The research described in this paper aims to answer three questions, asserted as objectives:

- To deepen the knowledge of the European construction industry.

- To highlights differences in the construction industry performance characteristics among European countries.

- To establish econometrics models that could be used to predict the behaviour of the European construction industry.

It is the intention of the authors that the results would enhance the corpus of Pan European Construction industry knowledge and could be utilised to predict future national Construction Industry behaviours based on Pan European macroeconomic input data.

Regarding the structure of the paper, production functions are proposed as mathematical models to explain differences among countries through time. As suggested by Ofori (2003), a panel of countries is considered in the research and both the cross-sectional and time series data from 1996 to 2005 are examined. The sources of data available are first enumerated; afterwards the variables are selected and justified for the proposed models. The econometric regression models are established and verified; the results are also analysed and then debated. Finally, the limitations of the research are discussed and conclusions are drawn. 


\section{DATA SOURCES}

Generally, the success of any econometric analysis depends on the availability of the appropriate data (Gujarati, 2003). This is especially true in the construction sector, as several authors have asserted (Ofori, 2000; Ruddock, 2000; Lopes et al., 2002). The quantitative analysis of these real economic phenomena is based on the concurrent development of theory and observation, related by appropriate methods of inference. The types of data available for empirical analysis are time series, cross-section and pooled data (a combination of the former two); pooled data becomes a panel if the same cross-sectional unit is surveyed over time.

The Statistical Office of the European Communities (Eurostat) publishes harmonised data on Switzerland and each of the EU countries (Eurostat, 2007). Within Eurostat, the BACH Project (Bank for the Accounts of Companies Harmonised) contains information of accounts from most European countries, in addition to data from the United States and Japan. It is collected via official agencies in each country using information provided voluntarily by construction companies. The data available in the $\mathrm{BACH}$ Project corresponds to the period 1996-2005 (Eurostat, 2006). The nine countries studied are Austria (AUT), Belgium (BEL), Germany (DEU), Spain (ESP), Finland (FIN), France (FRA), Italy (ITA), The Netherlands (NLD) and Portugal (POR); these will be referred to as EU-9 from now on. For Finland, the series begins in 1999.

As can be inferred, the United Kingdom is the only major country in terms of construction output, which is not analysed herein given the lack of accurate data. Furthermore, even for the chosen nine, the additional problem of the multiple sources of data persists, even though it is channelled through the Eurostat office. 
According to the European Commission (2003), three criteria can be considered to define a SME: number of employees, annual turnover, or annual balance sheet. Even though the most frequently used criterion is the number of employees, this research will utilise the annual turnover to avoid any distortions resulting from the subcontracting of manpower in the sector. Small companies (SM) are those with a business turnover less than 10 million Euros; medium companies (MD) are those whose business output is between 10 and 50 million Euros; finally, large companies (LG) are those that have a business volume over 50 million Euros. Significant data related to the number of workers and companies per size of company and per country are given in table 1.

\section{INSERT TABLE 1 HERE}

The construction industry replicates a similar business structure in each of the countries. This sector is characterised by a small number of large organisations and, to the contrary, a large number of small companies. The average number of workers per company (of any size) is 49 ; this figure is within the range of a medium enterprise, according to the definition of the European Commission (2003). Nevertheless, this means that $96 \%$ of the companies employ an average of 18 workers, and only $1 \%$ employs an average of 1,043 employees, as observed from the data in table 1 for EU-9.

Differences between the average number of workers for the EU-9 and each individual country can be summarised as follows. More smaller companies are located in Finland, Belgium and The Netherlands, whereas the larger ones are found in Germany, Italy and Spain, possibly because the importance of the industry in the overall economies of these countries prompted a concentration of 
enterprises, in the case of Germany at the beginning of the 1990s and in the case of Spain at the end of that decade.

\section{PRODUCTION FUNCTION AND VARIABLES}

A production function is a mathematical model that describes all the possible outputs or products that can be obtained from all the combinations of inputs that are efficient in a managerial activity. The production function supposes a given state of technology; each technological change modifies the production function. In general, the production function could be expressed, simply speaking, as a relationship between outputs (products) and inputs (capital and labour): $Q=f(K, L)$.

This research utilises a linear model with one independent variable and with two independent variables. The linear model expresses the dependent variable as a linear function of one or more independent variables. A bivariate or two-variable model relates the dependent variable to a single independent variable, whereas multivariate or multiple models relates the dependent variable to two or more independent variables. In this research, the linear model with one independent variable and with two independent variables, is used. They may be expressed as:

- $\mathrm{Q}=\mathrm{a}+\mathrm{b}^{\star} \mathrm{K}$ (two-variable linear model);

- $\mathrm{Q}=\mathrm{a}+\mathrm{c}^{*} \mathrm{~L}$ (two-variable linear model);

- $\quad \mathrm{Q}=\mathrm{a}+\mathrm{b}^{*} \mathrm{~K}+\mathrm{c} * \mathrm{~L}$ (three-variable linear model).

Finally, the classic Cobb-Douglas production function (logarithmic-linear with two independent variables) of economic analysis is used as well:

- $Q=e^{d_{*}} K^{\alpha *} L^{\beta}$. 
In this expression, the relationship between the output and the inputs (labour and capital) is non-linear, but can be linearised into a three-variable linear model by logarithmic transformation:

- $\ln Q=d+\alpha^{*} \ln K+\beta^{*} \ln L$.

The main property of the Cobb-Douglas function is that the sum $\alpha+\beta$ gives information about the returns to scale. If the sum is equal to 1 , there is constant return to scale. If the sum is less than 1 , there is decreasing return to scale. Finally, if the sum is greater than 1 , there is increasing return to scale.

Three types of variables are needed for the most generalised expression of the production function. For each type of variable, several series of data are available, as follows:

- Production (Q): i.e. number of companies or annual turnover.

- Capital (K): i.e. owner's equity, total assets or fixed assets.

- Labour (L): i.e. personnel costs or number of workers.

After preliminary analysis of the data, certain variables (number of companies, number of workers, owner's equity and fixed assets) must be discarded given the lack of consistency of the complete series. Thus, two variables are considered in this study:

- Dependent or explained variable: annual turnover (PR).

- Independent or explanatory variables: total assets (AC) and personnel costs (GP).

All variables are measured in thousands of Euros. They are homogenised by dividing the global magnitudes by the number of enterprises and obtaining the average per company for each country and year from 1996 to 2005 (except Finland, whose series is three years shorter); the average for the EU-9 per year 
is also included (EUTM). These panel data are presented in table 2, where logarithmic values of the three variables were also computed.

\section{INSERT TABLE 2 HERE}

Annual turnover for some countries is not as high as expected, according to the global data per country published officially (Eurostat, 2006; Seopan, 2006). This problem appears mainly in France and in Germany, the reason being that these countries obtain a lower voluntarily participation rate of companies in providing the information stored in the $\mathrm{BACH}$ Project. The evolution of annual turnover throughout the 1996-2005 period reflects three different scenarios that concur with reports from European organisations (Eurostat, 2006; Seopan, 2006):

- The turnover is almost constant, varying slightly through the years for Belgium, Finland and The Netherlands; this is noteworthy because it rose considerably in 2005, and was confirmed in 2006 as well (Seopan, 2007);

- The turnover increases for Portugal, and quite a lot for Spain, from 1996 onwards; the Spanish real estate boom is well reflected in the data;

- The turnover decreases at the start of the series and increases at the end for Austria, Germany, France and Italy; for the first two countries, the low period is considerable in magnitude and time, the recovery beginning in 2003, whereas, for France and Italy, it is light and short, with recovery starting in 1998.

The profile for the entire EU-9 is similar to that just described, with a decreased drop in 1999. It is clear that the influence of the German crisis is reflected in the global data, delaying the recovery year from 1998 to 1999. 
Regarding personnel costs, they do not increase in the same proportion as does the annual turnover. From the perspective of the construction industry, inconsistency can be found in the four major members:

- Germany: comparing 1998 to 2005 (the latter with a slightly higher turnover), the personnel costs dropped by $10 \%$;

- Spain: comparing 1996 to 2004 (similar personnel costs), the turnover in 2004 was up by $40 \%$;

- France: comparing 1996 to 2002 (similar personnel costs), the turnover during 2002 increased by 15\%;

- Italy: comparing 1996 to 2004 (similar turnover), the personnel costs decreased by $30 \%$.

For the entire EU-9, comparing 1997 to 2003 (similar turnover), personnel costs fell by $20 \%$. As discussed later, company size, informal economy, migration, and subcontracting may explain these differences.

As presented in table 3 , the statistics were calculated per country and per variable: mean (or average), standard deviation, minimum and maximum, using the statistical software SPSS for Windows.

\section{INSERT TABLE 3 HERE}

A correlation matrix per country was calculated and is presented in table 4. The coefficient of correlation ( $r$ ) measures the degree of association between two variables (or the sample co-variation between them). If the two variables are statistically independent, then the coefficient of correlation is zero; however, the opposite is not always true. The degree of correlation varies among the countries. It is very high for Austria, Germany and Portugal; fairly good for Finland, France 
and The Netherlands; and low for Italy. For the EUTR, it is better than for the EUTM.

\section{INSERT TABLE 4 HERE}

\section{REGRESSION MODELS}

Applying regression analysis to the econometric model yields the estimation of the production function. The regressions are estimated by means of the ordinary least squares method of the linear (or linearised) model. This regression analysis is set out as a linear function of k-1 explanatory variables and an independent term plus a random disturbance: $y=\alpha_{0}+\alpha_{1} \cdot x_{1}+\alpha_{2} x_{2}+\ldots+u$, where: $y$ is the dependent variable (or regressand); $x_{n}$ are the explanatory variables (or regressors); $\alpha_{n}$ are the parameters specified by the model; and $u$ is the error term.

Having established the general econometric model, and previously selected the available data, the production function is estimated using the previous equation applied to each of the established models. The time series analysis (1996-2005) was performed for countries and sizes of company, considering annual turnover (PR) as the dependent variable, and the following models and independent variables:

- Bivariate linear model, using total assets (AC) or personnel costs (GP) as independent variables;

- Multivariate linear model, using total assets (AC) and personnel costs (GP) as independent variables; 
- Cobb-Douglas model, using total assets (AC) and personnel costs (GP) as independent variables.

Table 5 offers the number and type of regressions carried out, adding a total of 176: 160 for temporal series and 16 for transversal series.

\section{INSERT TABLE 5 HERE}

Table 6 shows the results from the analysis per country for the bivariate linear model. The determination coefficient $\left(r^{2}\right)$ in the two-variable case measures the adequacy of fit of the regression equation. In the multiple-variable case, this quantity is the multiple coefficient of determination $\left(R^{2}\right)$. The adjusted determination coefficient is another summary statistic obtained from $R^{2}$. It penalizes the model for adding more regressors; for comparative purposes, the adjusted $\mathrm{R}^{2}$ (or R2C as in the tables) is a better measure than $\mathrm{R}^{2}$ only if the regressand is the same. The penalty for adding more regressors is carried further by the AIC (Akaike's Information Criterion); in comparing models, the one with the lowest value is preferred. Autocorrelation measures the degree of correlation between members of series of ordered data; it should be zero for a good fit of the regression model. The Durbin-Watson statistic (d) is very useful for detecting serial correlations; if $d$ is found to be 2 in an application, one may assume that there is no first-order autocorrelation, either positive or negative. Using this criterion, Austria and Finland should be discarded because this statistic is far from the theoretically optimum (2). Anyway, table 6 shows that there is a better adjustment for personnel costs, but not for every country.

INSERT TABLE 6 HERE 
Table 7 displays the analysis per country for the linear multivariate model. As inferred from Table 6, personnel costs (" $c$ " in table 7) account for a larger part of the production than the total assets ("b" in table 7). For the whole EU-9 this ratio is approximately 6.

\section{INSERT TABLE 7 HERE}

From table $8, \alpha+\beta$ can be inferred. This sum gives information on the economies of scale. Most of the results indicate that economies of scales do not exist, because this addition is less than 1 .

\section{INSERT TABLE 8 HERE}

Table 9 provides the best adjusted models. Only regressions with R2C better than 0.9 are presented. After this process of selection, only Austria and Portugal obtain positive results, whereas Germany, Finland, The Netherlands and the European Union as a whole obtain negative economies of scale.

INSERT TABLE 9 HERE

\section{ANALYSIS AND DISCUSSION OF RESULTS}

The construction industry in each nation is affected by problems that distort the data and provide a slightly different analysis per country. Many authors have stated the problems that influence the international, and naturally, the European construction industry (Winch, 2000; Ofori, 2003). Some of these 
problems must be considered in order to understand the results obtained in previous sections: unreliable data; predominance of the SME companies (DTI, 1998; Sorrell, 2003; Pearce, 2003; Eurostat, 2007); the informal economy undeclared work, shadow economy or black market - (Schneider and Enste, 2000; Schneider, 2002; Pearce, 2003; European Commission, 2004); the legal or illegal migration (Wells, 1996; Winch, 1998; Janssen, 2000; Fellini et al., 2007; Lillie and Greer, 2007); and the high degree of subcontracting (Winch, 1998; Druker and Croucher, 2000; Clarke and Wall, 2000; Fellini et al., 2007). These issues are discussed in the following paragraphs.

Even though the Eurostat Office, through the BACH Project, intends to give harmonised information on each of the countries and the EU as a whole, it is still far from achieving this ambitious purpose. This opinion has also been stated by some European organisations that also use Eurostat data as their source (Pearce, 2003; Seopan, 2007; Banco de España, 2007). They recognised not only the additional difficulty in obtaining data from the construction industry enterprises, but also the importance of obtaining accurate data that allows for a better analysis of the industry. According to Pearce (2003: p. ix): "Data are not always consistent or reliable and there are special problems of gathering a detailed picture of the broad industry beyond on-site construction". Nevertheless, the countries in the Euro zone have the advantage of a common currency; this becomes a weakness when comparing countries with different exchanges.

Furthermore, more countries have been joining the EU in recent years, some of them coming from socialist economic patterns of government. Every country has its own peculiarities, not only regarding economic, financial or fiscal issues but also cultural factors and weather conditions. Some of them agree easily to comply with the directives and give current and valuable data, whereas others see compliance from an intrusive point of view. This being said, the first 
step of the research was to identify clearly inconsistent data and, moreover, the countries that provided those data. Thus, the study ended up with only 9 countries.

Eurostat collects data from official agencies of the European Union Member States. However, as mentioned earlier, the data provided by the enterprises is voluntary. In fact, this implies a bias in the representativeness of the data, mainly in the SME companies, because their atomised and low qualified hierarchies make it difficult to provide the data voluntarily. The data in table 1 replicate a similar business structure in each one of the EU-9 members, characterised by a low number of large companies and a huge percentage of SME companies. Official data for the whole EU-27 (Eurostat, 2006) indicates that in 2005 there were 13,153,000 workers and 2,695,000 companies; noteworthy differences appear. The average number of workers is 49 for the EU-9, whereas it is 5 for the EU-27; the disparity is not only that more members are in the Union, but also that Eurostat obtains information from the companies on a voluntary basis, whereas the global data come from the official census. Regarding the number of enterprises and employees, only $3 \%$ and $12 \%$, respectively, of the official data for the EU-27 (Eurostat, 2007) are represented in the Bach Project (table 1). Whatever the case may be, it is more difficult to identify economies of scale and cost reductions in SME companies (Pearce, 2003).

Informal economies exist, even though sometimes governments do not like to discuss its existence, especially inside the EU. Four main kinds of undeclared work are generally considered: multiple job holders; the inactive population; the unemployed; and illegal migrant labour (Eurofound, 2008). It is difficult to compile information on this issue (Pearce, 2003). Padraig Flynn, former EU Commissioner for Social Affairs, issued a communication on the informal economy in the EU-15 (Eurofound, 2008), affecting construction, among other 
sectors; values fluctuate between $4 \%$ of the GDP in Finland to $21 \%$ in Belgium, $23 \%$ in Spain, $26 \%$ in Italy, and $35 \%$ in Greece. The informal economy is growing, being approximately $18 \%$ in European OECD countries (Schneider, 2002), with values varying from $29 \%$ in Greece, $27 \%$ in Italy and $22 \%$ in Spain, Belgium and Portugal, to $12 \%$ in the United Kingdom and $10 \%$ in Austria. Schneider (2002) showed that informal employment totalled some $48 \%$ in Italy, and half that value in Germany. Finally, the European Commission issued a report (European Commission, 2004) on undeclared work for the EU-15 and the candidate countries, citing figures ranging from $20 \%$ in Greece and $17 \%$ in Italy to $1 \%$ in Austria.

Subcontracting has also been increasing in the construction industry since the economic crisis of the 1970s (Winch, 1998). It is also interrelated with migration flows (Wells, 1996; Drewer, 2001). Some studies have approached the international mobility of workers and the employment policies by companies. Fellini et al. (2007) claimed that the hiring of foreign workers in the formal market has an indirect effect which escalated the informal migrant flows; this issue is especially important where SME subcontractors engage them, or in some countries like Italy and Portugal. In the construction industry, the hiring of migrant workers affects subcontractors, mainly; most of them are SME companies that are engaged by large companies, and also influence the market (Fellini et al., 2007). This idea concurs with the results displayed in table 2, where personnel costs did not increase significantly until 2005 for the whole EU-9, whereas turnover showed a constant raise since 1999. The growth of subcontracting and hiring of migrant workers slowed the rise of personnel costs in the industry, till a point (2005) where the escalating demand was so important that personnel costs had to boost up too. 


\section{LIMITATIONS OF RESEARCH AND CONCLUSIONS}

This research analyses the European construction industry using panel data from 1996 to 2005 for each of the selected nine countries. The study contributes to expand somewhat the knowledge of the construction industry, from a European perspective, considering the outstanding importance of the industry for the whole economy. The paper also highlights differences among the countries under analysis.

In the previous section, some factors that could explain the results were suggested, in agreement with other referenced authors, such as the diverse preponderance of SMEs and the different roles played by informal economy, migration and subcontracting in each of the countries. Discrepancies and inconsistencies in some of the results were a direct consequence of the data limitations. The main difficulty was accessing relevant information, not only for the whole European Union, but also for each of the member states. The findings are incomplete because of data constraints, and future studies are certainly needed so as to contribute to the global knowledge of the construction industry.

The macroeconomic analysis was performed using production functions. Regression models were proposed that could be tested using future data to predict the behaviour of the construction industry in each of the countries. The use of production functions in the construction industry is an approach that should be further developed and applied to gather more precise information on the behaviour of the sector in each of the countries, not only in the EU but also worldwide. 


\section{ACKNOWLEDGMENTS}

The research described in this paper is partially funded by the Spanish Ministry of Infrastructures (project 2004-36). The authors wish to thank Dr. Debra Westall for revising the text. Finally, the valuable suggestions of the anonymous reviewers are also acknowledged.

\section{REFERENCES}

Banco de España (2007) Annual Report 2006. Banco de España, Madrid.

Bon, R. (1988) Direct and indirect resource utilisation by the construction sector.

The case of the USA since World War II. Habitat International, 12(1), 4974

Bon, R. (2000) Economic structure and maturity. Ashgate Publishing Ltd., Aldershot.

Bon, R., Crosthwaite, D. (2001) The future of international construction: some results of 1992-1999 surveys, Building Research \& Information, 29(3), 242-247.

Bon, R., Pietroforte, R. (1990) Historical comparison of construction sectors in the United States, Japan, Italy and Finland using input-output tables. Construction Management and Economics, 8, 233-247

Clarke, L., Wall, C. (2000) Craft versus industry: the division of labour in European housing construction. Construction Management and Economics, 18, 689-698.

Dikmen, I., Birgonul, M.T., Budayan, C. (2009) Strategic group analysis in the construction industry. Journal of Construction Engineering and 
Management, 135(4), 288-297

Drewer, S. (2001) A perspective of the international construction system. Habitat International, 25, 69-79.

Druker, J., Croucher, R. (2000) National collective bargaining and employment flexibility in the European building and civil engineering industries. Construction Management and Economics, 18, 699-709.

DTI (1998) Rethinking construction (the 'Egan Report'). DTI (Department of Trade and Industry), London.

Eurofound (2008) Commission targets undeclared work. Retrieved the $28^{\text {th }}$ of March from http://www.eurofound.europa.eu/eiro/1998/04/feature/eu9804197f.htm. European Commission (2003) The new SME definition. User guide and model declaration. Office for Official Publications of the European Communities, Luxembourg.

European Commission (2004) Undeclared work in an enlarged Union. Office for Official Publications of the European Communities, Luxembourg.

Eurostat (2002) SMEs in Europe: Competitiveness, innovation and the knowledge-driven society (data 1996-2001). Office for Official Publications of the European Communities, Luxembourg.

Eurostat (2006) Europe in figures. Eurostat yearbook 2005-06. Office for Official Publications of the European Communities, Luxembourg.

Eurostat (2007) Europe in figures. Eurostat yearbook 2006-07. Office for Official Publications of the European Communities, Luxembourg.

Fellini, I., Ferro, A., Fullin, G. (2007) Recruitment processes and labour mobility: the construction industry in Europe. Work, employment and society, 21(2), 277-298.

Gann, D.M. (2000) Building innovation. Complex constructs in a changing world. Thomas Telford, London. 
Gujarati, D.N. (2003) Basic econometrics. McGraw-Hill, New York.

Hua, G.B., Pin, T.H. (2000) Forecasting construction industry demand, price and productivity in Singapore: the Box-Jenkins approach. Construction Management and Economics, 18, 607-618

Janssen, J. (2000) The European construction industry and its competitiveness: a construct of the European Commission. Construction Management and Economics, 18, 711-720.

Lillie, N., Greer, I. (2007) Industrial relations, migration, and neoliberal politics: The case of the European construction sector. Politics \& Society, 35, $551-581$.

Lopes, J., Ruddock, L., Ribeiro, F.L. (2002) Investment in construction and economic growth in developing countries. Building Research \& Information, 30(3), 152-159

Miozzo, M., Dewick, P. (2002) Building competitive advantage: innovation and corporate governance in European construction. Research Policy, 31, 989-1008.

Ngowi, A.B., Pienaar, E., Talukhaba, A., Mbachu, J. (2005) The globalisation of the construction industry - a review. Building and Environment, 40, 135141.

Ofori, G. (2000) Globalization and construction industry development: research opportunities. Construction Management and Economics, 18, 257-262.

Ofori, G. (2003) Frameworks for analysing international construction. Construction Management and Economics, 21, 379-391.

Pearce, D. (2003) The social and economic value of construction. The Construction Industry's Contribution to Sustainable Development. nCRISP Management Support Unit, London.

Pietroforte, R., Gregori, T. (2003) An input-output análisis of the construction 
sector in highly developed countries. Construction Management and Economics, 21, 319-327

Pries, F., Janszen, F. (1995) Innovation in the construction industry: the dominant role of the environment. Construction Management and Economics, 13, 43-51.

Ruddock, L. (2000) An international survey of macroeconomic and market information on the construction sector: issues of availability and reliability. RICS Foundation, Research Papers, 3(11)

Ruddock, L. (2002) Measuring the global construction industry: improving the quality of data. Construction Management and Economics, 20, 553-556

Ruddock, L., Lopes, J. (2006) The construction sector and economic development: the 'Bon curve'. Construction Management and Economics, 24, 717-723

Schneider, F. (2002) The size and development of the shadow economies of 22 transition and 21 OECD countries. Institute for the Study of Labor, IZA DP No. 514, Bonn.

Schneider, F., Enste, D. (2000) Informal economies: size, causes and consequences. Journal of Economic Literature, 38(1), 77-114.

Seopan (2006) Spanish Construction Activity Report 2005, Seopan, Madrid. Seopan (2007) Spanish Construction Activity Report 2006, Seopan, Madrid. Sorrell, S. (2003) Making the link: climate policy and the reform of the UK construction industry. Energy Policy, 31, 865-878.

Wells, J. (1996) Labour migration and international construction. Habitat International, 20(2), 295-306.

Winch, G.M. (1998) The growth of self-employment in British construction. Construction Management and Economics, 16(5), 531 - 542.

Winch, G.M. (2000) Construction business systems in the European Union. 
Building Research \& Information, 28(2), 88-97.

Wong, J.M.W., Chiang, Y.H., Ng, T.S. (2008) Construction and economic development: the case of Hong Kong. Construction Management and Economics, 26(8), 815-826. 
TABLE 1: BACH PROJECT DATA: TIME SERIES FROM 1996 TO 2005 PER COUNTRY

\begin{tabular}{|c|c|c|c|c|}
\hline COUNTRY & SIZE OF COMPANY & $\begin{array}{r}\text { NUMBER OF WORKERS } \\
\text { (in thousands) }\end{array}$ & $\begin{array}{r}\text { NUMBER OF COMPANIES } \\
\text { (in thousands) }\end{array}$ & WORKERS PER COMPANY \\
\hline \multirow{4}{*}{ AUT (Austria) } & TOTAL & 67,880 & 2,570 & 32 \\
\hline & SM & 45,314 & 2,530 & 19 \\
\hline & MD & 5,185 & 26 & 195 \\
\hline & LG & 17,381 & 14 & 1,252 \\
\hline \multirow{4}{*}{ BEL (Belgium) } & TOTAL & 157,999 & 23,973 & 7 \\
\hline & SM & 110,525 & 23,667 & 5 \\
\hline & MD & 31,514 & 268 & 119 \\
\hline & LG & 15,960 & 39 & 419 \\
\hline \multirow{4}{*}{ DEU (Germany) } & TOTAL & 201,040 & 2,918 & 72 \\
\hline & SM & 57,059 & 2,462 & 23 \\
\hline & MD & 49,799 & 384 & 131 \\
\hline & LG & 94,183 & 73 & 1,261 \\
\hline \multirow{4}{*}{ ESP (Spain) } & TOTAL & 122,532 & 749 & 166 \\
\hline & SM & 22,504 & 572 & 39 \\
\hline & MD & 15,057 & 124 & 125 \\
\hline & LG & 84,970 & 53 & 1,634 \\
\hline \multirow{4}{*}{ FIN (Finland) } & TOTAL & 99,736 & 17,917 & 5 \\
\hline & SM & 61,166 & 17,779 & 3 \\
\hline & MD & 11,212 & 106 & 107 \\
\hline & LG & 27,358 & 32 & 858 \\
\hline \multirow{4}{*}{ FRA (France) } & TOTAL & 626,448 & 18,657 & 34 \\
\hline & SM & 383,582 & 17,625 & 22 \\
\hline & MD & 112,965 & 886 & 132 \\
\hline & LG & 129,901 & 146 & 924 \\
\hline \multirow{4}{*}{ ITA (Italy) } & TOTAL & 139,631 & 1,772 & 82 \\
\hline & SM & 33,113 & 1,006 & 33 \\
\hline & MD & 53,712 & 671 & 84 \\
\hline & LG & 52,806 & 94 & 578 \\
\hline \multirow{4}{*}{$\begin{array}{l}\text { NLD (The } \\
\text { Netherlands) }\end{array}$} & TOTAL & 99,261 & 10,179 & 10 \\
\hline & $\mathrm{SM}$ & $\mathrm{n}, \mathrm{a}$ & 9,854 & n.a. \\
\hline & MD & $n, a$ & 265 & n.a. \\
\hline & LG & 99,261 & 60 & 1,679 \\
\hline \multirow{4}{*}{ POR (Portugal) } & TOTAL & 78,897 & 2,304 & 38 \\
\hline & SM & 36,936 & 2,173 & 18 \\
\hline & MD & 18,076 & 97 & 197 \\
\hline & LG & 23,884 & 34 & 781 \\
\hline \multirow{4}{*}{ UE9 (9 countries) } & TOTAL & $1,593,425$ & 81,039 & 49 \\
\hline & SM & 750,200 & 77,669 & 18 \\
\hline & MD & 297,521 & 2,826 & 121 \\
\hline & LG & 545,704 & 544 & 1,043 \\
\hline
\end{tabular}


TABLE 2: VARIABLES: TIME SERIES FROM 1996 TO 2005 PER COUNTRY

\begin{tabular}{|c|c|c|c|c|c|c|c|}
\hline COUNTRY & YEAR & PR & $A C$ & GP & LnPR & LnAC & LnGP \\
\hline \multirow{10}{*}{ AUT } & 1996 & $6,285.831$ & $6,219.137$ & $2,340.215$ & 8.746 & 8.735 & 7.758 \\
\hline & 1997 & $3,674.233$ & $3,163.676$ & $1,327.868$ & 8.209 & 8.059 & 7.191 \\
\hline & 1998 & $3,707.474$ & $3,011.960$ & $1,296.874$ & 8.218 & 8.010 & 7.168 \\
\hline & 1999 & $3,191.379$ & $2,511.649$ & $1,145.067$ & 8.068 & 7.829 & 7.043 \\
\hline & 2000 & 2,179.295 & $1,828.257$ & 775.611 & 7.687 & 7.511 & 6.654 \\
\hline & 2001 & $1,977.623$ & $1,503.957$ & 699.090 & 7.590 & 7.316 & 6.550 \\
\hline & 2002 & $2,139.813$ & $1,732.274$ & 754.070 & 7.668 & 7.457 & 6.625 \\
\hline & 2003 & $2,240.065$ & $1,589.339$ & 784.023 & 7.714 & 7.371 & 6.664 \\
\hline & 2004 & $3,760.821$ & $2,896.032$ & $1,287.705$ & 8.232 & 7.971 & 7.161 \\
\hline & 2005 & $5,353.429$ & $4,001.787$ & $1,720.592$ & 8.585 & 8.294 & 7.450 \\
\hline \multirow{10}{*}{ BEL } & 1996 & 936.817 & 854.038 & 238.233 & 6.842 & 6.750 & 5.473 \\
\hline & 1997 & 940.957 & 806.827 & 224.324 & 6.847 & 6.693 & 5.413 \\
\hline & 1998 & 938.968 & 780.542 & 221.502 & 6.845 & 6.660 & 5.400 \\
\hline & 1999 & 959.971 & 821.904 & 225.497 & 6.867 & 6.712 & 5.418 \\
\hline & 2000 & $1,006.812$ & 849.454 & 228.949 & 6.915 & 6.745 & 5.433 \\
\hline & 2001 & $1,028.932$ & 870.352 & 233.568 & 6.936 & 6.769 & 5.453 \\
\hline & 2002 & $1,005.542$ & 855.506 & 231.978 & 6.913 & 6.752 & 5.447 \\
\hline & 2003 & $1,012.512$ & 823.473 & 226.499 & 6.920 & 6.714 & 5.423 \\
\hline & 2004 & 992.543 & 752.449 & 218.459 & 6.900 & 6.623 & 5.387 \\
\hline & 2005 & $1,060.777$ & 944.771 & 213.534 & 6.967 & 6.851 & 5.364 \\
\hline \multirow{10}{*}{ DEU } & 1996 & $15,653.215$ & $18,476.848$ & $4,692.834$ & 9.658 & 9.824 & 8.454 \\
\hline & 1997 & $16,948.554$ & $19,188.669$ & $4,623.566$ & 9.738 & 9.862 & 8.439 \\
\hline & 1998 & $10,394.167$ & $10,268.102$ & $2,956.101$ & 9.249 & 9.237 & 7.992 \\
\hline & 1999 & $10,313.110$ & $10,352.632$ & $2,917.579$ & 9.241 & 9.245 & 7.979 \\
\hline & 2000 & $10,666.074$ & $10,218.169$ & $2,847.842$ & 9.275 & 9.232 & 7.954 \\
\hline & 2001 & $9,483.441$ & $8,228.783$ & $2,623.120$ & 9.157 & 9.015 & 7.872 \\
\hline & 2002 & $9,885.695$ & $8,416.254$ & $2,694.840$ & 9.199 & 9.038 & 7.899 \\
\hline & 2003 & $8,966.486$ & $9,075.359$ & $2,524.962$ & 9.101 & 9.113 & 7.834 \\
\hline & 2004 & $9,222.346$ & $7,966.276$ & $2,357.232$ & 9.129 & 8.983 & 7.765 \\
\hline & 2005 & $10,584.239$ & $9,279.192$ & $2,654.527$ & 9.267 & 9.136 & 7.884 \\
\hline \multirow{10}{*}{ ESP } & 1996 & $23,224.674$ & $27,521.890$ & $5,285.936$ & 10.053 & 10.223 & 8.573 \\
\hline & 1997 & $23,806.248$ & $27,143.933$ & $4,923.132$ & 10.078 & 10.209 & 8.502 \\
\hline & 1998 & $26,572.715$ & $32,707.129$ & $5,359.717$ & 10.188 & 10.395 & 8.587 \\
\hline & 1999 & $25,638.451$ & $32,967.730$ & $5,061.030$ & 10.152 & 10.403 & 8.529 \\
\hline & 2000 & $26,122.404$ & $37,319.792$ & $5,031.175$ & 10.171 & 10.527 & 8.523 \\
\hline & 2001 & $28,592.453$ & $38,159.366$ & $4,997.961$ & 10.261 & 10.550 & 8.517 \\
\hline & 2002 & $29,068.367$ & $42,064.876$ & $4,924.181$ & 10.277 & 10.647 & 8.502 \\
\hline & 2003 & $29,948.189$ & $43,328.888$ & $4,791.710$ & 10.307 & 10.677 & 8.475 \\
\hline & 2004 & $32,634.919$ & $37,420.100$ & $5,459.822$ & 10.393 & 10.530 & 8.605 \\
\hline & 2005 & $38,841.435$ & $48,853.568$ & $6,144.715$ & 10.567 & 10.797 & 8.723 \\
\hline \multirow{7}{*}{ FIN } & 1999 & 685.130 & 371.269 & 156.141 & 6.530 & 5.917 & 5.051 \\
\hline & 2000 & 783.624 & 464.470 & 178.118 & 6.664 & 6.141 & 5.182 \\
\hline & 2001 & 855.431 & 506.333 & 200.171 & 6.752 & 6.227 & 5.299 \\
\hline & 2002 & 788.920 & 483.111 & 183.187 & 6.671 & 6.180 & 5.211 \\
\hline & 2003 & 778.398 & 510.550 & 179.109 & 6.657 & 6.235 & 5.188 \\
\hline & 2004 & 811.803 & 521.080 & 184.442 & 6.699 & 6.256 & 5.217 \\
\hline & 2005 & 821.488 & 504.544 & 185.081 & 6.711 & 6.224 & 5.221 \\
\hline \multirow{10}{*}{ FRA } & 1996 & $3,656.986$ & $3,041.997$ & $1,158.533$ & 8.204 & 8.020 & 7.055 \\
\hline & 1997 & $3,851.713$ & $3,056.516$ & $1,162.062$ & 8.256 & 8.025 & 7.058 \\
\hline & 1998 & $3,711.556$ & $2,814.242$ & $1,110.126$ & 8.219 & 7.942 & 7.012 \\
\hline & 1999 & $3,926.613$ & $2,867.208$ & $1,128.116$ & 8.276 & 7.961 & 7.028 \\
\hline & 2000 & $4,258.150$ & $3,027.679$ & $1,184.192$ & 8.357 & 8.016 & 7.077 \\
\hline & 2001 & $4,232.390$ & $3,131.446$ & $1,168.140$ & 8.351 & 8.049 & 7.063 \\
\hline & 2002 & $4,182.666$ & $3,072.529$ & $1,176.166$ & 8.339 & 8.030 & 7.070 \\
\hline & 2003 & $4,285.151$ & $3,184.665$ & $1,200.271$ & 8.363 & 8.066 & 7.090 \\
\hline & 2004 & $4,441.064$ & $3,262.329$ & $1,240.833$ & 8.399 & 8.090 & 7.124 \\
\hline & 2005 & $4,713.342$ & $3,645.924$ & $1,296.169$ & 8.458 & 8.201 & 7.167 \\
\hline \multirow{10}{*}{ ITA } & 1996 & $18,147.471$ & $28,776.420$ & $3,598.643$ & 9.806 & 10.267 & 8.188 \\
\hline & 1997 & $13,773.324$ & $20,018.198$ & $2,610.045$ & 9.530 & 9.904 & 7.867 \\
\hline & 1998 & $13,862.237$ & $19,929.615$ & $2,369.056$ & 9.537 & 9.900 & 7.770 \\
\hline & 1999 & $15,218.489$ & $23,923.846$ & $2,489.745$ & 9.630 & 10.083 & 7.820 \\
\hline & 2000 & $16,348.572$ & $25,888.205$ & $2,651.738$ & 9.702 & 10.162 & 7.883 \\
\hline & 2001 & $19,199.338$ & $30,057.064$ & $2,833.822$ & 9.863 & 10.311 & 7.949 \\
\hline & 2002 & $18,921.953$ & $31,707.636$ & $2,717.193$ & 9.848 & 10.364 & 7.907 \\
\hline & 2003 & $19,497.003$ & $24,678.422$ & $2,659.391$ & 9.878 & 10.114 & 7.886 \\
\hline & 2004 & $17,836.622$ & $20,859.681$ & $2,432.915$ & 9.789 & 9.946 & 7.797 \\
\hline & 2005 & $21,214.826$ & $35,055.257$ & $2,647.610$ & 9.962 & 10.465 & 7.881 \\
\hline
\end{tabular}




\begin{tabular}{|c|c|c|c|c|c|c|c|}
\hline COUNTRY & YEAR & PR & $\mathrm{AC}$ & GP & LnPR & LnAC & LnGP \\
\hline \multirow{10}{*}{ NLD } & 1996 & $3,235.803$ & $1,857.558$ & 816.070 & 8.082 & 7.527 & 6.704 \\
\hline & 1997 & $3,375.888$ & $2,003.769$ & 845.998 & 8.124 & 7.603 & 6.741 \\
\hline & 1998 & $3,402.837$ & $1,995.302$ & 862.960 & 8.132 & 7.599 & 6.760 \\
\hline & 1999 & $3,732.972$ & $2,515.962$ & 916.445 & 8.225 & 7.830 & 6.821 \\
\hline & 2000 & $3,978.877$ & $3,080.954$ & 931.057 & 8.289 & 8.033 & 6.836 \\
\hline & 2001 & $4,300.989$ & $3,108.622$ & $1,037.829$ & 8.367 & 8.042 & 6.945 \\
\hline & 2002 & $4,219.327$ & $3,374.677$ & $1,051.456$ & 8.347 & 8.124 & 6.958 \\
\hline & 2003 & $3,777.151$ & 2,663.310 & 993.391 & 8.237 & 7.887 & 6.901 \\
\hline & 2004 & $3,633.125$ & $2,642.622$ & 969.318 & 8.198 & 7.880 & 6.877 \\
\hline & 2005 & $4,735.789$ & $3,211.657$ & $1,154.585$ & 8.463 & 8.075 & 7.051 \\
\hline \multirow{10}{*}{ POR } & 1996 & $1,880.344$ & $2,147.443$ & 334.513 & 7.539 & 7.672 & 5.813 \\
\hline & 1997 & $2,132.658$ & $2,224.169$ & 340.799 & 7.665 & 7.707 & 5.831 \\
\hline & 1998 & $2,196.129$ & $2,402.425$ & 340.620 & 7.694 & 7.784 & 5.831 \\
\hline & 1999 & $2,237.677$ & $2,722.683$ & 367.650 & 7.713 & 7.909 & 5.907 \\
\hline & 2000 & $4,323.583$ & $4,841.711$ & 686.153 & 8.372 & 8.485 & 6.531 \\
\hline & 2001 & $5,622.666$ & $6,710.621$ & 858.019 & 8.635 & 8.811 & 6.755 \\
\hline & 2002 & $6,132.358$ & $7,734.823$ & 941.930 & 8.721 & 8.953 & 6.848 \\
\hline & 2003 & $6,569.060$ & $9,210.240$ & 985.359 & 8.790 & 9.128 & 6.893 \\
\hline & 2004 & $7,735.813$ & $9,861.332$ & $1,021.901$ & 8.954 & 9.196 & 6.929 \\
\hline & 2005 & $8,228.466$ & $11,269.036$ & $1,141.288$ & 9.015 & 9.330 & 7.040 \\
\hline \multirow{10}{*}{ EUTM } & 1996 & $9,127.643$ & $11,111.916$ & $2,308.122$ & 8.616 & 8.627 & 7.252 \\
\hline & 1997 & $8,562.947$ & $9,700.720$ & $2,007.224$ & 8.556 & 8.508 & 7.130 \\
\hline & 1998 & $8,098.260$ & $9,238.665$ & $1,814.620$ & 8.510 & 8.441 & 7.065 \\
\hline & 1999 & $7,322.643$ & $8,783.876$ & $1,600.808$ & 8.300 & 8.210 & 6.844 \\
\hline & 2000 & $7,740.821$ & $9,724.299$ & $1,612.759$ & 8.381 & 8.317 & 6.897 \\
\hline & 2001 & $8,365.918$ & $10,252.949$ & $1,627.969$ & 8.434 & 8.343 & 6.934 \\
\hline & 2002 & $8,482.738$ & $11,049.076$ & $1,630.556$ & 8.443 & 8.394 & 6.941 \\
\hline & 2003 & $8,563.780$ & $10,562.694$ & $1,593.857$ & 8.441 & 8.367 & 6.928 \\
\hline & 2004 & $9,007.673$ & $9,575.767$ & $1,685.847$ & 8.522 & 8.386 & 6.985 \\
\hline & 2005 & $10,617.088$ & $12,973.971$ & $1,906.456$ & 8.666 & 8.597 & 7.087 \\
\hline
\end{tabular}


TABLE 3. STATISTICS PER VARIABLE AND PER COUNTRY

\begin{tabular}{|c|c|c|c|c|c|c|}
\hline STATISTICS & PR & $A C$ & GP & LnPR & LnAC & LnGP \\
\hline \multicolumn{7}{|l|}{ AUT } \\
\hline Mean & $3,450.996$ & $2,845.807$ & $1,213.111$ & 8.072 & 7.855 & 7.026 \\
\hline St. Desviación & $1,449.450$ & $1,438.097$ & 517.337 & 0.402 & 0.453 & 0.400 \\
\hline Minimum & $1,977.623$ & $1,503.957$ & 699.090 & 7.590 & 7.316 & 6.550 \\
\hline Maximum & $6,285.831$ & $6,219.137$ & $2,340.215$ & 8.746 & 8.735 & 7.758 \\
\hline \multicolumn{7}{|l|}{ BEL } \\
\hline Mean & 988.383 & 835.932 & 226.254 & 6.895 & 6.727 & 5.421 \\
\hline St. Desviación & 42.526 & 52.874 & 7.352 & 0.043 & 0.063 & 0.033 \\
\hline Minimum & 936.817 & 752.449 & 213.534 & 6.842 & 6.623 & 5.364 \\
\hline Maximum & $1,060.777$ & 944.771 & 238.233 & 6.967 & 6.851 & 5.473 \\
\hline \multicolumn{7}{|l|}{ DEU } \\
\hline Mean & $11,211.733$ & $11,147.028$ & $3,089.260$ & 9.302 & 9.269 & 8.007 \\
\hline St. Desviación & $2,759.820$ & $4,143.693$ & 846.376 & 0.218 & 0.317 & 0.241 \\
\hline Minimum & $8,966.486$ & $7,966.276$ & $2,357.232$ & 9.101 & 8.983 & 7.765 \\
\hline Maximum & $16,948.554$ & $19,188.669$ & $4,692.834$ & 9.738 & 9.862 & 8.454 \\
\hline \multicolumn{7}{|l|}{ ESP } \\
\hline Mean & $28,444.985$ & $36,748.727$ & $5,197.938$ & 10.245 & 10.496 & 8.554 \\
\hline St. Desviación & $4,641.092$ & $6,903.067$ & 394.534 & 0.154 & 0.190 & 0.073 \\
\hline Minimum & $23,224.674$ & $27,143.933$ & $4,791.710$ & 10.053 & 10.209 & 8.475 \\
\hline Maximum & $38,841.435$ & $48,853.568$ & $6,144.715$ & 10.567 & 10.797 & 8.723 \\
\hline \multicolumn{7}{|l|}{ FIN } \\
\hline Mean & 789.256 & 480.194 & 180.893 & 6.669 & 6.169 & 5.196 \\
\hline St. Desviación & 53.101 & 51.623 & 13.106 & 0.070 & 0.117 & 0.074 \\
\hline Minimum & 685.130 & 371.269 & 156.141 & 6.530 & 5.917 & 5.051 \\
\hline Maximum & 855.431 & 521.080 & 200.171 & 6.752 & 6.256 & 5.299 \\
\hline \multicolumn{7}{|l|}{ FRA } \\
\hline Mean & $4,125.963$ & $3,110.453$ & $1,182.461$ & 8.322 & 8.040 & 7.074 \\
\hline St. Desviación & 334.711 & 230.588 & 53.827 & 0.081 & 0.072 & 0.045 \\
\hline Minimum & $3,656.986$ & $2,814.242$ & $1,110.126$ & 8.204 & 7.942 & 7.012 \\
\hline Maximum & $4,713.342$ & $3,645.924$ & $1,296.169$ & 8.458 & 8.201 & 7.167 \\
\hline \multicolumn{7}{|l|}{ ITA } \\
\hline Mean & $17,401.983$ & $26,089.434$ & $2,701.016$ & 9.755 & 10.151 & 7.895 \\
\hline St. Desviación & $2,511.897$ & $5,204.560$ & 344.098 & 0.149 & 0.199 & 0.116 \\
\hline Minimum & $13,773.324$ & $19,929.615$ & $2,369.056$ & 9.530 & 9.900 & 7.770 \\
\hline Maximum & $21,214.826$ & $35,055.257$ & $3,598.643$ & 9.962 & 10.465 & 8.188 \\
\hline \multicolumn{7}{|l|}{ NLD } \\
\hline Mean & $3,839.276$ & $2,645.443$ & 957.911 & 8.246 & 7.860 & 6.859 \\
\hline St. Desviación & 472.333 & 550.643 & 105.044 & 0.121 & 0.218 & 0.108 \\
\hline Minimum & $3,235.803$ & $1,857.558$ & 816.070 & 8.082 & 7.527 & 6.704 \\
\hline Maximum & $4,735.789$ & $3,374.677$ & $1,154.585$ & 8.463 & 8.124 & 7.051 \\
\hline \multicolumn{7}{|l|}{ POR } \\
\hline Mean & $4,705.875$ & $5,912.449$ & 701.823 & 8.310 & 8.498 & 6.438 \\
\hline St. Desviación & $2,473.819$ & $3,504.605$ & 327.560 & 0.593 & 0.671 & 0.527 \\
\hline Minimum & $1,880.344$ & $2,147.443$ & 334.513 & 7.539 & 7.672 & 5.813 \\
\hline Maximum & $8,228.466$ & $11,269.036$ & $1,141.288$ & 9.015 & 9.330 & 7.040 \\
\hline \multicolumn{7}{|l|}{ EUTM } \\
\hline Mean & $8,588.95$ & $10,297.39$ & $1,778.82$ & 8.49 & 8.42 & 7.01 \\
\hline St. Desviación & 894.73 & $1,205.62$ & 234.94 & 0.11 & 0.13 & 0.12 \\
\hline Minimum & $7,322.64$ & $8,783.88$ & $1,593.86$ & 8.30 & 8.21 & 6.84 \\
\hline Maximum & $10,617.09$ & $12,973.97$ & $2,308.12$ & 8.67 & 8.63 & 7.25 \\
\hline \multicolumn{7}{|l|}{ EUTR } \\
\hline Mean & $10,617.088$ & $12,973.971$ & $1,906.456$ & 8.666 & 8.597 & 7.087 \\
\hline St. Desviación & $12,242.647$ & $17,155.504$ & $1,818.607$ & 1.254 & 1.515 & 1.148 \\
\hline Minimum & 821.488 & 504.544 & 185.081 & 6.711 & 6.224 & 5.221 \\
\hline Maximum & $38,841.435$ & $48,853.568$ & $6,144.715$ & 10.567 & 10.797 & 8.723 \\
\hline
\end{tabular}


TABLE 4. CORRELATION MATRIX PER COUNTRY

\begin{tabular}{|c|c|c|c|c|c|c|}
\hline & PR & $A C$ & GP & LnPR & LnAC & LnGP \\
\hline \multicolumn{7}{|l|}{ AUT } \\
\hline PR & 1 & 0.971772 & 0.990367 & 0.985287 & 0.980635 & 0.983916 \\
\hline$A C$ & 0.971772 & 1 & 0.993278 & 0.937985 & 0.972743 & 0.957671 \\
\hline GP & 0.990367 & 0.993278 & 1 & 0.969631 & 0.985448 & 0.981450 \\
\hline LnPR & 0.985287 & 0.937985 & 0.969631 & 1 & 0.984011 & 0.995375 \\
\hline $\operatorname{LnAC}$ & 0.980635 & 0.972743 & 0.985448 & 0.984011 & 1 & 0.993833 \\
\hline LnGP & 0.983916 & 0.957671 & 0.981450 & 0.995375 & 0.993833 & 1 \\
\hline \multicolumn{7}{|l|}{ BEL } \\
\hline PR & 1 & 0.632244 & -0.274616 & 0.999830 & 0.618280 & -0.279262 \\
\hline$A C$ & 0.632244 & 1 & 0.060136 & 0.622344 & 0.999138 & 0.049431 \\
\hline GP & -0.274616 & 0.060136 & 1 & -0.268994 & 0.095021 & 0.999843 \\
\hline LnPR & 0.999830 & 0.622344 & -0.268994 & 1 & 0.608678 & -0.273425 \\
\hline LnAC & 0.618280 & 0.999138 & 0.095021 & 0.608678 & 1 & 0.084625 \\
\hline LnGP & -0.279262 & 0.049431 & 0.999843 & -0.273425 & 0.084625 & 1 \\
\hline \multicolumn{7}{|l|}{ DEU } \\
\hline PR & 1 & 0.985633 & 0.981984 & 0.997791 & 0.975747 & 0.977028 \\
\hline$A C$ & 0.985633 & 1 & 0.992163 & 0.981193 & 0.995808 & 0.987298 \\
\hline GP & 0.981984 & 0.992163 & 1 & 0.980596 & 0.986475 & 0.997525 \\
\hline LnPR & 0.997791 & 0.981193 & 0.980596 & 1 & 0.975508 & 0.979013 \\
\hline $\operatorname{Ln} A C$ & 0.975747 & 0.995808 & 0.986475 & 0.975508 & 1 & 0.986865 \\
\hline LnGP & 0.977028 & 0.987298 & 0.997525 & 0.979013 & 0.986865 & 1 \\
\hline \multicolumn{7}{|l|}{ ESP } \\
\hline PR & 1.000000 & 0.872744 & 0.692592 & 0.996317 & 0.851497 & 0.673481 \\
\hline$A C$ & 0.872744 & 1.000000 & 0.359914 & 0.891202 & 0.995534 & 0.333899 \\
\hline GP & 0.692592 & 0.359914 & 1.000000 & 0.643016 & 0.316588 & 0.999224 \\
\hline LnPR & 0.996317 & 0.891202 & 0.643016 & 1.000000 & 0.876906 & 0.624304 \\
\hline $\operatorname{Ln} A C$ & 0.851497 & 0.995534 & 0.316588 & 0.876906 & 1.000000 & 0.292380 \\
\hline LnGP & 0.673481 & 0.333899 & 0.999224 & 0.624304 & 0.292380 & 1.000000 \\
\hline \multicolumn{7}{|l|}{ FIN } \\
\hline PR & 1 & 0.883803 & 0.982437 & 0.999280 & 0.888416 & 0.985908 \\
\hline$A C$ & 0.883803 & 1 & 0.848223 & 0.896088 & 0.999134 & 0.867422 \\
\hline GP & 0.982437 & 0.848223 & 1 & 0.979568 & 0.853425 & 0.998882 \\
\hline LnPR & 0.999280 & 0.896088 & 0.979568 & 1 & 0.901401 & 0.984773 \\
\hline LnAC & 0.888416 & 0.999134 & 0.853425 & 0.901401 & 1 & 0.873324 \\
\hline LnGP & 0.985908 & 0.867422 & 0.998882 & 0.984773 & 0.873324 & 1 \\
\hline \multicolumn{7}{|l|}{ FRA } \\
\hline PR & 1 & 0.837108 & 0.888021 & 0.999226 & 0.839221 & 0.889029 \\
\hline$A C$ & 0.837108 & 1 & 0.969082 & 0.819731 & 0.998884 & 0.966878 \\
\hline GP & 0.888021 & 0.969082 & 1 & 0.873790 & 0.970606 & 0.999663 \\
\hline LnPR & 0.999226 & 0.819731 & 0.873790 & 1 & 0.822977 & 0.875497 \\
\hline $\operatorname{LnAC}$ & 0.839221 & 0.998884 & 0.970606 & 0.822977 & 1 & 0.969597 \\
\hline LnGP & 0.889029 & 0.966878 & 0.999663 & 0.875497 & 0.969597 & 1 \\
\hline \multicolumn{7}{|l|}{ ITA } \\
\hline PR & 1 & 0.810856 & 0.326964 & 0.998148 & 0.812370 & 0.358692 \\
\hline$A C$ & 0.810856 & 1 & 0.439032 & 0.802553 & 0.996634 & 0.474781 \\
\hline GP & 0.326964 & 0.439032 & 1 & 0.344159 & 0.469185 & 0.997777 \\
\hline LnPR & 0.998148 & 0.802553 & 0.344159 & 1 & 0.808125 & 0.375430 \\
\hline LnAC & 0.812370 & 0.996634 & 0.469185 & 0.808125 & 1 & 0.505587 \\
\hline LnGP & 0.358692 & 0.474781 & 0.997777 & 0.375430 & 0.505587 & 1 \\
\hline \multicolumn{7}{|l|}{ NLD } \\
\hline PR & 1 & 0.909615 & 0.949015 & 0.998346 & 0.899965 & 0.944711 \\
\hline$A C$ & 0.909615 & 1 & 0.876277 & 0.927841 & 0.997099 & 0.890169 \\
\hline GP & 0.949015 & 0.876277 & 1 & 0.948906 & 0.875206 & 0.998543 \\
\hline LnPR & 0.998346 & 0.927841 & 0.948906 & 1 & 0.920744 & 0.947657 \\
\hline LnAC & 0.899965 & 0.997099 & 0.875206 & 0.920744 & 1 & 0.891704 \\
\hline LnGP & 0.944711 & 0.890169 & 0.998543 & 0.947657 & 0.891704 & 1 \\
\hline \multicolumn{7}{|l|}{ POR } \\
\hline PR & 1 & 0.993622 & 0.992198 & 0.987933 & 0.989749 & 0.977015 \\
\hline$A C$ & 0.993622 & 1 & 0.985343 & 0.972405 & 0.983286 & 0.961891 \\
\hline GP & 0.992198 & 0.985343 & 1 & 0.994218 & 0.996470 & 0.993394 \\
\hline LnPR & 0.987933 & 0.972405 & 0.994218 & 1 & 0.995911 & 0.995909 \\
\hline $\operatorname{Ln} A C$ & 0.989749 & 0.983286 & 0.996470 & 0.995911 & 1 & 0.993296 \\
\hline LnGP & 0.977015 & 0.961891 & 0.993394 & 0.995909 & 0.993296 & 1 \\
\hline \multicolumn{7}{|l|}{ EUTM } \\
\hline PR & 1 & 0.867929 & 0.476713 & 0.881101 & 0.793327 & 0.575220 \\
\hline$A C$ & 0.867929 & 1 & 0.343809 & 0.667551 & 0.675597 & 0.396650 \\
\hline $\mathrm{GP}$ & 0.476713 & 0.343809 & 1 & 0.770065 & 0.871310 & 0.966414 \\
\hline LnPR & 0.881101 & 0.667551 & 0.770065 & 1 & 0.962160 & 0.873540 \\
\hline
\end{tabular}




\begin{tabular}{|c|c|c|c|c|c|c|}
\hline & PR & $A C$ & GP & LnPR & LnAC & LnGP \\
\hline LnAC & 0.793327 & 0.675597 & 0.871310 & 0.962160 & 1 & 0.937262 \\
\hline LnGP & 0.575220 & 0.396650 & 0.966414 & 0.873540 & 0.937262 & 1 \\
\hline \multicolumn{7}{|l|}{ UETR } \\
\hline $\begin{array}{l}\mathrm{PR} \\
\end{array}$ & 1 & 0.980637 & 0.961859 & 0.853172 & 0.856325 & 0.776278 \\
\hline$A C$ & 0.980637 & 1 & 0.895469 & 0.833767 & 0.861146 & 0.721988 \\
\hline GP & 0.961859 & 0.895469 & 1 & 0.862643 & 0.829505 & 0.850173 \\
\hline LnPR & 0.853172 & 0.833767 & 0.862643 & 1 & 0.987303 & 0.967687 \\
\hline LnAC & 0.856325 & 0.861146 & 0.829505 & 0.987303 & 1 & 0.919789 \\
\hline LnGP & 0.776278 & 0.721988 & 0.850173 & 0.967687 & 0.919789 & 1 \\
\hline
\end{tabular}


TABLE 5. NUMBER OF REGRESSIONS

\begin{tabular}{lrrr}
\hline TYPE & Time series & Transversal series (2005 data) & TOTAL \\
\hline Bivariates & 80 & 8 & 88 \\
Multivariates & 40 & 4 & 44 \\
Logarithmics & 40 & 4 & 44 \\
TOTAL & 160 & 16 & 176 \\
\hline
\end{tabular}


TABLE 6. SERIES ANALYSIS PER COUNTRY FOR THE BIVARIATE LINEAR MODEL

\begin{tabular}{|c|c|c|c|c|c|c|c|c|c|c|}
\hline COUNTRY & SIZE & REGRESSOR & a & b & C & R2C & AIC & Prob $>F$ & D-W & AUTOC \\
\hline \multirow[t]{8}{*}{$\overline{A U T}$} & LG & GP & $9,731.016$ & & 2.946 & 0.869 & 21.819 & 0.000 & 1.253 & 0.373 \\
\hline & & $\mathrm{AC}$ & $24,038.122$ & 0.913 & & 0.596 & 22.947 & 0.005 & 1.208 & 0.396 \\
\hline & MD & GP & $21,499.021$ & & 0.141 & -0.114 & 16.778 & 0.785 & 2.056 & -0.028 \\
\hline & & $A C$ & $21,665.229$ & 0.039 & & 0.028 & 16.642 & 0.295 & 1.403 & 0.299 \\
\hline & SM & GP & -244.155 & & 3.085 & 0.980 & 10.883 & 0.000 & 0.722 & 0.639 \\
\hline & & $A C$ & 12.611 & 1.461 & & 0.855 & 12.842 & 0.000 & 1.141 & 0.430 \\
\hline & TOTAL & GP & 84.896 & & 2.775 & 0.978 & 13.736 & 0.000 & 0.638 & 0.681 \\
\hline & & $A C$ & 663.689 & 0.979 & & 0.937 & 14.802 & 0.000 & 0.655 & 0.673 \\
\hline \multirow[t]{8}{*}{ BEL } & LG & GP & $65,462.357$ & & 1.757 & -0.089 & 22.111 & 0.619 & 0.397 & 0.802 \\
\hline & & $A C$ & $79,936.386$ & 0.149 & & -0.040 & 22.065 & 0.441 & 0.190 & 0.905 \\
\hline & MD & GP & $21,464.745$ & & 0.419 & -0.093 & 14.580 & 0.641 & 1.105 & 0.448 \\
\hline & & $A C$ & $21,608.945$ & -0.122 & & 0.279 & 14.165 & 0.067 & 1.679 & 0.161 \\
\hline & SM & GP & 716.197 & & -0.651 & 0.025 & 7.630 & 0.300 & 1.112 & 0.444 \\
\hline & & $A C$ & 412.216 & 0.450 & & 0.755 & 6.248 & 0.001 & 1.772 & 0.114 \\
\hline & TOTAL & GP & $1,347.581$ & & -1.588 & -0.040 & 10.554 & 0.443 & 0.672 & 0.664 \\
\hline & & $A C$ & 563.304 & 0.509 & & 0.325 & 10.122 & 0.050 & 0.415 & 0.792 \\
\hline \multirow[t]{8}{*}{ DEU } & LG & GP & $75,783.222$ & & 2.667 & 0.824 & 21.894 & 0.000 & 2.212 & -0.106 \\
\hline & & $A C$ & $91,440.487$ & 0.485 & & 0.875 & 21.558 & 0.000 & 2.511 & -0.255 \\
\hline & MD & GP & $22,036.022$ & & -0.328 & -0.104 & 15.584 & 0.707 & 1.626 & 0.187 \\
\hline & & $A C$ & $20,804.077$ & -0.039 & & -0.118 & 15.596 & 0.827 & 1.547 & 0.226 \\
\hline & SM & GP & $1,121.630$ & & 1.834 & 0.842 & 11.472 & 0.000 & 1.121 & 0.440 \\
\hline & & $A C$ & $1,460.448$ & 0.773 & & 0.736 & 11.984 & 0.001 & 1.594 & 0.203 \\
\hline & TOTAL & $A C$ & $3,894.162$ & 0.656 & & 0.968 & 15.422 & 0.000 & 2.314 & -0.157 \\
\hline & & GP & $1,319.926$ & & 3.202 & 0.960 & 15.646 & 0.000 & 2.163 & -0.081 \\
\hline \multirow[t]{8}{*}{ ESP } & LG & GP & $193,457.939$ & & 2.284 & -0.101 & 24.545 & 0.687 & 0.216 & 0.892 \\
\hline & & $A C$ & $139,798.455$ & 0.424 & & 0.619 & 23.484 & 0.004 & 0.848 & 0.576 \\
\hline & MD & GP & $10,230.037$ & & 3.223 & 0.758 & 15.628 & 0.001 & 2.134 & -0.067 \\
\hline & & $A C$ & $19,401.699$ & 0.083 & & -0.027 & 17.074 & 0.407 & 1.776 & 0.112 \\
\hline & SM & GP & -129.334 & & 3.784 & 0.762 & 12.893 & 0.001 & 1.524 & 0.238 \\
\hline & & $A C$ & 801.707 & 0.765 & & 0.768 & 12.864 & 0.001 & 0.847 & 0.576 \\
\hline & TOTAL & GP & $-13,904.012$ & & 8.147 & 0.415 & 19.365 & 0.026 & 0.361 & 0.820 \\
\hline & & $A C$ & $6,882.083$ & 0.587 & & 0.732 & 18.584 & 0.001 & 1.119 & 0.440 \\
\hline \multirow[t]{8}{*}{ FIN } & LG & GP & $20,432.760$ & & 4.875 & 0.840 & 20.996 & 0.002 & 1.365 & 0.318 \\
\hline & & $A C$ & $-35,550.896$ & 2.032 & & 0.814 & 21.146 & 0.003 & 1.068 & 0.466 \\
\hline & MD & GP & $11,616.529$ & & 1.930 & 0.258 & 15.296 & 0.140 & 1.600 & 0.200 \\
\hline & & $A C$ & $20,087.352$ & -0.061 & & -0.155 & 15.738 & 0.678 & 1.550 & 0.225 \\
\hline & SM & GP & 67.899 & & 2.908 & 0.889 & 6.325 & 0.001 & 1.726 & 0.137 \\
\hline & & $A C$ & 287.329 & 0.307 & & 0.421 & 7.978 & 0.068 & 1.419 & 0.291 \\
\hline & TOTAL & GP & 69.208 & & 3.981 & 0.958 & 7.842 & 0.000 & 1.034 & 0.483 \\
\hline & & $A C$ & 352.706 & 0.909 & & 0.737 & 9.680 & 0.008 & 1.573 & 0.213 \\
\hline \multirow[t]{8}{*}{$\overline{F R A}$} & LG & GP & $52,763.219$ & & 2.434 & 0.944 & 19.129 & 0.000 & 2.543 & -0.272 \\
\hline & & $A C$ & $84,019.818$ & 0.384 & & 0.852 & 20.095 & 0.000 & 2.524 & -0.262 \\
\hline & MD & GP & $16,720.119$ & & 0.395 & 0.411 & 12.760 & 0.027 & 2.226 & -0.113 \\
\hline & & $A C$ & $18,211.464$ & 0.029 & & -0.102 & 13.386 & 0.691 & 1.174 & 0.413 \\
\hline & SM & GP & $-2,432.736$ & & 6.599 & 0.826 & 11.363 & 0.000 & 0.551 & 0.725 \\
\hline & & $A C$ & 643.447 & 1.204 & & 0.953 & 10.061 & 0.000 & 2.961 & -0.480 \\
\hline & TOTAL & GP & $-2,403.727$ & & 5.522 & 0.762 & 13.205 & 0.001 & 0.401 & 0.799 \\
\hline & & $A C$ & 346.423 & 1.215 & & 0.663 & 13.553 & 0.003 & 0.539 & 0.731 \\
\hline \multirow[t]{8}{*}{ ITA } & LG & GP & $75,271.075$ & & 3.422 & -0.067 & 23.440 & 0.527 & 0.288 & 0.856 \\
\hline & & $A C$ & $83,035.859$ & 0.282 & & 0.691 & 22.201 & 0.002 & 1.029 & 0.486 \\
\hline & MD & GP & $17,959.341$ & & -0.265 & -0.114 & 17.177 & 0.788 & 1.494 & 0.253 \\
\hline & & $A C$ & $12,351.013$ & 0.225 & & -0.014 & 17.083 & 0.377 & 1.026 & 0.487 \\
\hline & SM & GP & $4,311.761$ & & 1.420 & -0.083 & 15.600 & 0.592 & 0.282 & 0.859 \\
\hline & & $A C$ & $5,181.142$ & 0.050 & & 0.152 & 15.356 & 0.145 & 0.444 & 0.778 \\
\hline & TOTAL & GP & $10,955.096$ & & 2.387 & -0.005 & 18.677 & 0.356 & 0.434 & 0.783 \\
\hline & & $\mathrm{AC}$ & 7,191.977 & 0.391 & & 0.615 & 17.719 & 0.004 & 0.990 & 0.505 \\
\hline \multirow[t]{8}{*}{ NLD } & LG & GP & $97,595.428$ & & 3.417 & 0.884 & 22.585 & 0.000 & 1.432 & 0.284 \\
\hline & & $A C$ & $195,950.101$ & 0.616 & & 0.601 & 23.824 & 0.005 & 1.514 & 0.243 \\
\hline & MD & GP & $4,979.907$ & & 3.268 & 0.805 & 14.658 & 0.000 & 1.327 & 0.337 \\
\hline & & $A C$ & $12,045.181$ & 0.644 & & 0.647 & 15.250 & 0.003 & 1.571 & 0.215 \\
\hline & SM & GP & -264.991 & & 3.720 & 0.820 & 9.726 & 0.000 & 1.416 & 0.292 \\
\hline & & $A C$ & 602.563 & 0.797 & & 0.483 & 10.782 & 0.015 & 0.820 & 0.590 \\
\hline & TOTAL & GP & -248.375 & & 4.267 & 0.888 & 13.139 & 0.000 & 1.105 & 0.447 \\
\hline & & $A C$ & $1,775.154$ & 0.780 & & 0.806 & 13.691 & 0.000 & 1.969 & 0.015 \\
\hline \multirow[t]{4}{*}{ POR } & LG & GP & $103,787.031$ & & 1.984 & 0.141 & 21.359 & 0.154 & 1.043 & $\overline{0.479}$ \\
\hline & & $A C$ & $124,085.484$ & 0.116 & & -0.097 & 21.603 & 0.661 & 0.909 & 0.546 \\
\hline & MD & GP & $10,230.037$ & & 3.223 & 0.758 & 15.628 & 0.001 & 2.134 & -0.067 \\
\hline & & $A C$ & $19,401.699$ & 0.083 & & -0.027 & 17.074 & 0.407 & 1.776 & 0.112 \\
\hline
\end{tabular}




\begin{tabular}{|c|c|c|c|c|c|c|c|c|c|c|}
\hline COUNTRY & SIZE & REGRESSOR & a & b & C & R2C & AIC & Prob>F & D-W & AUTOC \\
\hline & \multirow[t]{2}{*}{ SM } & GP & 134.764 & & \multirow[t]{2}{*}{4.425} & 0.908 & 12.018 & 0.000 & 0.855 & 0.573 \\
\hline & & $A C$ & 595.515 & 0.237 & & 0.928 & 11.770 & 0.000 & 0.626 & 0.687 \\
\hline & \multirow[t]{2}{*}{ TOTAL } & GP & -553.114 & & \multirow[t]{2}{*}{7.493} & 0.983 & 14.595 & 0.000 & 1.341 & 0.329 \\
\hline & & $A C$ & 559.035 & 0.701 & & 0.986 & 14.395 & 0.000 & 2.265 & -0.133 \\
\hline \multirow[t]{8}{*}{ EUTM } & \multirow[t]{2}{*}{ LG } & GP & $129,354.119$ & & \multirow[t]{2}{*}{1.667} & -0.006 & 22.135 & 0.358 & 0.403 & 0.798 \\
\hline & & $A C$ & $52,986.890$ & 0.691 & & 0.387 & 21.640 & 0.032 & 1.322 & 0.339 \\
\hline & \multirow[t]{2}{*}{ MD } & GP & $19,692.594$ & & \multirow[t]{2}{*}{-0.003} & -0.125 & 14.327 & 0.994 & 1.581 & 0.209 \\
\hline & & $A C$ & $17,312.115$ & 0.131 & & 0.139 & 14.060 & 0.156 & 1.269 & 0.366 \\
\hline & \multirow[t]{2}{*}{ SM } & GP & $1,631.770$ & & \multirow[t]{2}{*}{0.961} & -0.042 & 12.040 & 0.449 & 0.619 & 0.691 \\
\hline & & $A C$ & $2,125.732$ & 0.026 & & -0.101 & 12.095 & 0.684 & 0.865 & 0.568 \\
\hline & \multirow[t]{2}{*}{ TOTAL } & GP & $5,359.443$ & & \multirow[t]{2}{*}{1.816} & 0.131 & 6.468 & 0.164 & 0.404 & 0.798 \\
\hline & & $A C$ & $1,956.243$ & 0.644 & & 0.723 & 15.326 & 0.001 & 1.299 & 0.350 \\
\hline \multirow[t]{8}{*}{ EUTR } & \multirow[t]{2}{*}{$\overline{L G}$} & GP & $58,567.716$ & & \multirow[t]{2}{*}{4.010} & 0.709 & 25.056 & 0.003 & 2.500 & -0.250 \\
\hline & & $A C$ & $96,163.026$ & 0.532 & & 0.367 & 25.834 & 0.049 & 2.066 & -0.033 \\
\hline & \multirow[t]{2}{*}{ MD } & GP & $16,369.656$ & & \multirow[t]{2}{*}{0.798} & 0.722 & 16.457 & 0.002 & 1.620 & 0.190 \\
\hline & & $A C$ & $20,291.593$ & -0.022 & & -0.134 & 17.865 & 0.826 & 1.605 & 0.197 \\
\hline & \multirow[t]{2}{*}{ SM } & GP & -145.144 & & \multirow[t]{2}{*}{4.208} & 0.707 & 16.779 & 0.003 & 2.307 & -0.153 \\
\hline & & $A C$ & 869.879 & 0.599 & & 0.695 & 16.820 & 0.003 & 1.543 & 0.229 \\
\hline & \multirow[t]{2}{*}{ TOTAL } & GP & $-1,727.445$ & & \multirow[t]{2}{*}{6.475} & 0.915 & 19.397 & 0.000 & 1.637 & 0.181 \\
\hline & & $A C$ & $1,537.776$ & 0.700 & & 0.956 & 18.729 & 0.000 & 1.814 & $0.0 \mathrm{~s}$ \\
\hline
\end{tabular}


TABLE 7. SERIES ANALYSIS PER COUNTRY FOR THE MULTIVARIATE LINEAR MODEL

\begin{tabular}{|c|c|c|c|c|c|c|c|c|c|c|}
\hline COUNTRY & SIZE & REGRESSOR & a & b & C & R2C & AIC & Prob>F & D-W & AUTOC \\
\hline \multirow[t]{4}{*}{$\overline{\text { AUT }}$} & LG & $A C ; G P$ & $17,345.255$ & -0.261 & 3.590 & 0.864 & 21.928 & 0.000 & 1.506 & 0.247 \\
\hline & MD & $A C ; G P$ & $16,316.711$ & 0.063 & 0.609 & 0.055 & 16.679 & 0.340 & 0.955 & 0.523 \\
\hline & SM & $A C ; G P$ & -247.338 & -0.100 & 3.274 & 0.977 & 11.060 & 0.000 & 0.893 & 0.554 \\
\hline & TOTAL & $A C ; G P$ & -367.413 & -0.898 & 5.254 & 0.989 & 13.127 & 0.000 & 1.737 & 0.132 \\
\hline \multirow[t]{4}{*}{ BEL } & LG & $A C ; G P$ & $46,011.661$ & 0.151 & 1.825 & -0.143 & 22.227 & 0.663 & 0.233 & 0.883 \\
\hline & MD & $A C ; G P$ & $17,733.723$ & -0.181 & 1.064 & 0.305 & 14.194 & 0.116 & 1.641 & 0.180 \\
\hline & SM & $A C ; G P$ & 240.145 & 0.590 & 0.730 & 0.839 & 5.894 & 0.001 & 2.382 & -0.191 \\
\hline & TOTAL & $A C ; G P$ & 961.004 & 0.524 & -1.814 & 0.354 & 10.144 & 0.090 & 0.518 & 0.741 \\
\hline \multirow[t]{4}{*}{ DEU } & LG & $A C ; G P$ & $89,557.542$ & 0.447 & 0.219 & 0.857 & 21.755 & 0.001 & 2.503 & -0.252 \\
\hline & MD & $A C ; G P$ & $24,600.219$ & 0.236 & -1.438 & -0.231 & 15.759 & 0.858 & 1.659 & 0.171 \\
\hline & SM & $A C ; G P$ & 1,058.635 & -0.271 & 2.421 & 0.827 & 11.626 & 0.001 & 1.157 & 0.421 \\
\hline & TOTAL & $A C ; G P$ & $3,187.424$ & 0.484 & 0.851 & 0.965 & 15.584 & 0.000 & 2.275 & -0.138 \\
\hline \multirow[t]{4}{*}{ ESP } & LG & $A C ; G P$ & $-35,623.730$ & 0.431 & 3.074 & 0.614 & 23.563 & 0.015 & 0.987 & 0.507 \\
\hline & MD & $A C ; G P$ & $9,957.113$ & 0.023 & 3.149 & 0.732 & 15.797 & 0.004 & 2.243 & -0.121 \\
\hline & SM & $A C ; G P$ & 19.437 & 0.433 & 2.084 & 0.851 & 12.492 & 0.001 & 1.713 & 0.144 \\
\hline & TOTAL & $A C ; G P$ & $-15,837.858$ & 0.482 & 5.115 & 0.905 & 17.611 & 0.000 & 2.314 & -0.157 \\
\hline \multirow[t]{4}{*}{ FIN } & LG & $A C ; G P$ & $-16,755.878$ & 0.982 & 2.831 & 0.867 & 20.873 & 0.008 & 1.128 & 0.436 \\
\hline & MD & $A C ; G P$ & $2,224.890$ & 0.224 & 3.640 & 0.374 & 15.188 & 0.174 & 1.604 & 0.198 \\
\hline & SM & $A C ; G P$ & 69.529 & 0.005 & 2.879 & 0.862 & 6.610 & 0.009 & 1.729 & 0.136 \\
\hline & TOTAL & $\mathrm{AC} ; \mathrm{GP}$ & 92.196 & 0.185 & 3.362 & 0.961 & 7.826 & 0.001 & 1.103 & 0.448 \\
\hline \multirow[t]{4}{*}{ FRA } & LG & $A C ; G P$ & $51,602.647$ & -0.019 & 2.543 & 0.936 & 19.325 & 0.000 & 2.537 & -0.268 \\
\hline & MD & $A C ; G P$ & $16,980.028$ & -0.030 & 0.427 & 0.350 & 12.925 & 0.092 & 2.222 & -0.111 \\
\hline & SM & $A C ; G P$ & 73.615 & 1.027 & 1.136 & 0.951 & 10.155 & 0.000 & 2.404 & -0.202 \\
\hline & TOTAL & $A C ; G P$ & $-3,410.249$ & -0.560 & 7.845 & 0.740 & 13.361 & 0.004 & 0.602 & 0.699 \\
\hline \multirow[t]{4}{*}{ ITA } & LG & $A C ; G P$ & $72,013.746$ & 0.279 & 0.599 & 0.649 & 22.395 & 0.011 & 0.946 & 0.527 \\
\hline & MD & $A C ; G P$ & $6,306.856$ & 0.923 & -3.169 & 0.383 & 16.653 & 0.077 & 2.613 & -0.307 \\
\hline & SM & $A C ; G P$ & $5,686.841$ & 0.053 & -0.530 & 0.036 & 15.551 & 0.366 & 0.513 & 0.744 \\
\hline & TOTAL & $\mathrm{AC} ; \mathrm{GP}$ & $7,702.164$ & 0.399 & -0.262 & 0.561 & 17.916 & 0.023 & 1.046 & 0.477 \\
\hline \multirow[t]{4}{*}{ NLD } & LG & $A C ; G P$ & $95,976.988$ & 0.207 & 2.732 & 0.915 & 22.344 & 0.000 & 2.018 & -0.009 \\
\hline & MD & $A C ; G P$ & 6,157.024 & 0.236 & 2.415 & 0.823 & 14.627 & 0.001 & 1.245 & 0.378 \\
\hline & $\mathrm{SM}$ & $A C ; G P$ & -307.686 & -0.099 & 4.031 & 0.798 & 9.910 & 0.002 & 1.472 & 0.264 \\
\hline & TOTAL & $\mathrm{AC} ; \mathrm{GP}$ & 257.458 & 0.288 & 2.943 & 0.906 & 13.033 & 0.000 & 1.400 & 0.300 \\
\hline \multirow[t]{4}{*}{ POR } & LG & $A C ; G P$ & $91,974.595$ & 0.086 & 1.942 & 0.036 & 21.541 & 0.365 & 1.054 & 0.473 \\
\hline & MD & $A C ; G P$ & $9,957.113$ & 0.023 & 3.149 & 0.732 & 15.797 & 0.004 & 2.243 & -0.121 \\
\hline & SM & $A C ; G P$ & 342.749 & 0.135 & 2.154 & 0.976 & 10.762 & 0.000 & 1.104 & 0.448 \\
\hline & TOTAL & $A C ; G P$ & 22.553 & 0.387 & 3.410 & 0.991 & 13.966 & 0.000 & 2.807 & -0.403 \\
\hline \multirow[t]{4}{*}{ EUTM } & LG & $A C ; G P$ & $19,616.987$ & 0.650 & 1.007 & 0.347 & 21.770 & 0.093 & 1.033 & 0.484 \\
\hline & MD & $A C ; G P$ & $17,755.701$ & 0.136 & -0.199 & 0.028 & 14.247 & 0.375 & 1.337 & 0.332 \\
\hline & SM & $A C ; G P$ & $1,443.147$ & 0.037 & 1.115 & -0.136 & 12.193 & 0.649 & 0.575 & 0.713 \\
\hline & TOTAL & $\mathrm{AC} ; \mathrm{GP}$ & $1,117.656$ & 0.593 & 0.770 & 0.729 & 15.368 & 0.004 & 1.328 & 0.336 \\
\hline \multirow[t]{4}{*}{ EUTR } & LG & $A C ; G P$ & -119.455 & 0.354 & 3.376 & 0.900 & 24.060 & 0.000 & 1.227 & 0.386 \\
\hline & MD & $A C ; G P$ & $14,494.983$ & 0.078 & 0.911 & 0.784 & 16.275 & 0.004 & 1.230 & 0.385 \\
\hline & SM & $A C ; G P$ & -257.220 & 0.387 & 2.764 & 0.949 & 15.103 & 0.000 & 2.139 & -0.069 \\
\hline & TOTAL & $A C ; G P$ & -382.142 & 0.430 & 2.845 & 0.996 & 16.392 & 0.000 & 0.974 & 0.513 \\
\hline
\end{tabular}


TABLE 8. SERIES ANALYSIS PER COUNTRY FOR THE COBB-DOUGLAS MODEL

\begin{tabular}{|c|c|c|c|c|c|c|c|c|c|c|}
\hline COUNTRY & SIZE & REGRESSOR & a & $\alpha$ & $\beta$ & R2C & AIC & Prob $>F$ & D-W & AUTOC \\
\hline \multirow[t]{4}{*}{$\overline{\text { AUT }}$} & LG & LnAC,LnGP & 3.003 & -0.213 & 1.064 & 0.841 & -2.271 & 0.001 & 1.367 & 0.317 \\
\hline & MD & LnAC, LnGP & 7.326 & 0.076 & 0.216 & 0.121 & -3.474 & 0.264 & 0.773 & 0.614 \\
\hline & SM & LnAC,LnGP & 0.246 & -0.035 & 1.154 & 0.966 & -3.679 & 0.000 & 0.819 & 0.591 \\
\hline & TOTAL & LnAC,LnGP & 1.012 & -0.377 & 1.426 & 0.991 & -3.450 & 0.000 & 1.324 & 0.338 \\
\hline \multirow[t]{4}{*}{ BEL } & LG & LnAC,LnGP & 6.294 & 0.113 & 0.394 & -0.181 & -0.854 & 0.744 & 0.263 & 0.869 \\
\hline & MD & LnAC, LnGP & 9.432 & -0.148 & 0.224 & 0.269 & -5.515 & 0.139 & 1.585 & 0.207 \\
\hline & SM & LnAC,LnGP & 2.955 & 0.430 & 0.167 & 0.832 & -6.925 & 0.001 & 2.373 & -0.186 \\
\hline & TOTAL & LnAC, LnGP & 6.302 & 0.436 & -0.432 & 0.327 & -3.610 & 0.104 & 0.510 & 0.745 \\
\hline \multirow[t]{4}{*}{ DEU } & LG & LnAC, LnGP & 5.019 & 0.412 & 0.196 & 0.842 & -2.814 & 0.001 & 2.545 & -0.273 \\
\hline & MD & LnAC,LnGP & 11.706 & 0.205 & -0.437 & -0.220 & -4.083 & 0.833 & 1.663 & 0.169 \\
\hline & SM & LnAC,LnGP & 3.673 & -0.172 & 0.813 & 0.836 & -4.330 & 0.001 & 1.187 & 0.407 \\
\hline & TOTAL & LnAC,LnGP & 2.495 & 0.246 & 0.565 & 0.951 & -2.981 & 0.000 & 2.051 & -0.026 \\
\hline \multirow[t]{4}{*}{ ESP } & LG & LnAC,LnGP & 0.425 & 0.574 & 0.440 & 0.678 & -1.943 & 0.008 & 1.016 & 0.492 \\
\hline & MD & LnAC,LnGP & 5.546 & 0.017 & 0.522 & 0.723 & -4.097 & 0.005 & 2.221 & -0.111 \\
\hline & $\mathrm{SM}$ & LnAC,LnGP & 0.656 & 0.427 & 0.587 & 0.851 & -3.514 & 0.001 & 1.796 & 0.102 \\
\hline & TOTAL & LnAC,LnGP & -3.497 & 0.614 & 0.854 & 0.893 & -2.898 & 0.000 & 2.192 & -0.096 \\
\hline \multirow[t]{4}{*}{ FIN } & LG & LnAC,LnGP & 0.386 & 0.565 & 0.498 & 0.880 & -3.423 & 0.006 & 1.118 & 0.441 \\
\hline & MD & LnAC, LnGP & 2.244 & 0.145 & 0.756 & 0.441 & -4.678 & 0.139 & 1.814 & 0.093 \\
\hline & SM & LnAC,LnGP & 2.211 & 0.003 & 0.794 & 0.872 & -5.176 & 0.007 & 1.731 & 0.135 \\
\hline & TOTAL & LnAC, LnGP & 1.985 & 0.103 & 0.779 & 0.966 & -5.560 & 0.001 & 1.077 & 0.462 \\
\hline \multirow[t]{4}{*}{ FRA } & LG & LnAC,LnGP & 5.059 & -0.008 & 0.656 & 0.946 & -4.650 & 0.000 & 2.491 & -0.245 \\
\hline & MD & LnAC,LnGP & 9.078 & -0.020 & 0.111 & 0.345 & -6.733 & 0.094 & 2.197 & -0.098 \\
\hline & SM & LnAC, LnGP & 1.002 & 0.612 & 0.352 & 0.955 & -5.358 & 0.000 & 2.477 & -0.239 \\
\hline & TOTAL & LnAC,LnGP & -4.337 & -0.489 & 2.345 & 0.714 & -3.194 & 0.005 & 0.621 & 0.689 \\
\hline \multirow[t]{4}{*}{ ITA } & LG & LnAC,LnGP & 4.872 & 0.513 & 0.072 & 0.621 & -1.371 & 0.014 & 0.991 & 0.504 \\
\hline & MD & LnAC, LnGP & 2.213 & 1.183 & -0.536 & 0.396 & -2.820 & 0.071 & 2.594 & -0.297 \\
\hline & SM & LnAC,LnGP & 8.267 & 0.115 & -0.098 & -0.008 & -1.700 & 0.426 & 0.404 & 0.798 \\
\hline & TOTAL & LnAC,LnGP & 3.900 & 0.621 & -0.057 & 0.556 & -1.544 & 0.024 & 0.995 & 0.502 \\
\hline \multirow[t]{4}{*}{ NLD } & LG & LnAC, LnGP & 4.382 & 0.130 & 0.604 & 0.924 & -3.324 & 0.000 & 1.920 & 0.040 \\
\hline & MD & LnAC,LnGP & 4.112 & 0.123 & 0.550 & 0.823 & -4.991 & 0.001 & 1.240 & 0.380 \\
\hline & SM & LnAC, LnGP & -0.225 & -0.054 & 1.284 & 0.808 & -4.489 & 0.001 & 1.478 & 0.261 \\
\hline & TOTAL & LnAC,LnGP & 1.918 & 0.205 & 0.688 & 0.905 & -3.500 & 0.000 & 1.457 & 0.272 \\
\hline \multirow[t]{4}{*}{ POR } & LG & LnAC,LnGP & 8.105 & 0.109 & 0.249 & 0.017 & -2.138 & 0.391 & 1.000 & 0.500 \\
\hline & MD & LnAC,LnGP & 5.546 & 0.017 & 0.522 & 0.723 & -4.097 & 0.005 & 2.221 & -0.111 \\
\hline & SM & LnAC,LnGP & 2.870 & 0.334 & 0.297 & 0.970 & -3.037 & 0.000 & 1.110 & 0.445 \\
\hline & TOTAL & LnAC,LnGP & 0.933 & 0.442 & 0.562 & 0.994 & -3.046 & 0.000 & 2.449 & -0.224 \\
\hline \multirow[t]{4}{*}{ EUTM } & LG & LnAC,LnGP & 5.784 & 0.635 & -0.132 & 0.075 & -2.387 & 0.316 & 0.859 & 0.571 \\
\hline & MD & LnAC, LnGP & 8.871 & 0.182 & -0.090 & 0.093 & -5.518 & 0.295 & 1.655 & 0.173 \\
\hline & SM & LnAC,LnGP & 1.799 & 0.442 & 0.393 & 0.818 & -4.492 & 0.001 & 1.275 & 0.363 \\
\hline & TOTAL & LnAC, LnGP & 1.409 & 1.011 & -0.204 & 0.913 & -3.780 & 0.000 & 1.777 & 0.112 \\
\hline \multirow[t]{4}{*}{ EUTR } & LG & LnAC,LnGP & 2.105 & 0.412 & 0.484 & 0.808 & -0.179 & 0.003 & 1.250 & 0.375 \\
\hline & MD & LnAC, LnGP & 7.205 & 0.091 & 0.217 & 0.690 & -3.255 & 0.013 & 0.942 & 0.529 \\
\hline & SM & LnAC, LnGP & 1.109 & 0.322 & 0.653 & 0.980 & -1.102 & 0.000 & 2.404 & -0.202 \\
\hline & TOTAL & LnAC,LnGP & 1.177 & 0.523 & 0.423 & 0.997 & -2.287 & 0.000 & 2.128 & -0.064 \\
\hline
\end{tabular}


TABLE 9. SELECTED MODELS

\begin{tabular}{|c|c|c|c|c|c|c|c|c|c|c|}
\hline MODEL & COUNTRY & REGRESSOR & a & $\alpha$ & $\beta$ & R2C & AIC & Prob $>F$ & D-W & AUTOC \\
\hline \multirow{9}{*}{ LINEAL BIVARIATE } & AUT & $\mathrm{AC}$ & 663.689 & 0.979 & & 0.937 & 14.802 & 0.000 & 0.655 & 0.673 \\
\hline & AUT & GP & 84.896 & & 2.775 & 0.978 & 13.736 & 0.000 & 0.638 & 0.681 \\
\hline & DEU & $A C$ & $3,894.162$ & 0.656 & & 0.968 & 15.422 & 0.000 & 2.314 & -0.157 \\
\hline & DEU & GP & $1,319.926$ & & 3.202 & 0.960 & 15.646 & 0.000 & 2.163 & -0.081 \\
\hline & FIN & GP & 69.208 & & 3.981 & 0.958 & 7.842 & 0.000 & 1.034 & 0.483 \\
\hline & POR & $A C$ & 559.035 & 0.701 & & 0.986 & 14.395 & 0.000 & 2.265 & -0.133 \\
\hline & POR & GP & -553.114 & & 7.493 & 0.983 & 14.595 & 0.000 & 1.341 & 0.329 \\
\hline & EUTR & AC & $1,537.776$ & 0.700 & & 0.956 & 18.729 & 0.000 & 1.814 & 0.093 \\
\hline & EUTR & GP & $-1,727.445$ & & 6.475 & 0.915 & 19.397 & 0.000 & 1.637 & 0.181 \\
\hline \multirow{7}{*}{ LINEAL MULTIVARIATE } & AUT & $\mathrm{AC} ; \mathrm{GP}$ & -367.413 & -0.898 & 5.254 & 0.989 & 13.127 & 0.000 & 1.737 & 0.132 \\
\hline & DEU & $A C ; G P$ & $3,187.424$ & 0.484 & 0.851 & 0.965 & 15.584 & 0.000 & 2.275 & -0.138 \\
\hline & ESP & $A C ; G P$ & $-15,837.858$ & 0.482 & 5.115 & 0.905 & 17.611 & 0.000 & 2.314 & -0.157 \\
\hline & FIN & $\mathrm{AC} ; \mathrm{GP}$ & 92.196 & 0.185 & 3.362 & 0.961 & 7.826 & 0.001 & 1.103 & 0.448 \\
\hline & NLD & $\mathrm{AC} ; \mathrm{GP}$ & 257.458 & 0.288 & 2.943 & 0.906 & 13.033 & 0.000 & 1.400 & 0.300 \\
\hline & POR & $\mathrm{AC} ; \mathrm{GP}$ & 22.553 & 0.387 & 3.410 & 0.991 & 13.966 & 0.000 & 2.807 & -0.403 \\
\hline & EUTR & $\mathrm{AC} ; \mathrm{GP}$ & -382.142 & 0.430 & 2.845 & 0.996 & 16.392 & 0.000 & 0.974 & 0.513 \\
\hline \multirow{6}{*}{ COBB-DOUGLAS } & AUT & LnAC,LnGP & 1.012 & -0.377 & 1.426 & 0.991 & -3.450 & 0.000 & 1.324 & 0.338 \\
\hline & DEU & LnAC,LnGP & 2.495 & 0.246 & 0.565 & 0.951 & -2.981 & 0.000 & 2.051 & -0.026 \\
\hline & FIN & LnAC,LnGP & 1.985 & 0.103 & 0.779 & 0.966 & -5.560 & 0.001 & 1.077 & 0.462 \\
\hline & NLD & LnAC,LnGP & 1.918 & 0.205 & 0.688 & 0.905 & -3.500 & 0.000 & 1.457 & 0.272 \\
\hline & POR & LnAC,LnGP & 0.933 & 0.442 & 0.562 & 0.994 & -3.046 & 0.000 & 2.449 & -0.224 \\
\hline & EUTR & LnAC,LnGP & 1.177 & 0.523 & 0.423 & 0.997 & -2.287 & 0.000 & 2.128 & -0.064 \\
\hline
\end{tabular}

